\title{
CONTROLS ON NITROGEN CYCLING IN TERRESTRIAL ECOSYSTEMS: A SYNTHETIC ANALYSIS OF LITERATURE DATA
}

\author{
Mary S. Booth, ${ }^{1,4}$ John M. Stark, ${ }^{2}$ And Edward Rastetter ${ }^{3}$ \\ ${ }^{1}$ Earth Institute, Columbia University, B-15 Hogan Hall, MC 3277, 2110 Broadway, New York, New York 10027 USA \\ ${ }^{2}$ Department of Biology, and the Ecology Center, Utah State University, 5305 Old Main Hill, \\ Logan, Utah 84322-5305 USA \\ ${ }^{3}$ The Ecosystems Center, Woods Hole Marine Biological Laboratory, 7 MBL Street, Woods Hole, \\ Massachusetts 02543 USA
}

\begin{abstract}
Isotope pool dilution studies are increasingly reported in the soils and ecology literature as a means of measuring gross rates of nitrogen (N) mineralization, nitrification, and inorganic $\mathrm{N}$ assimilation in soils. We assembled data on soil characteristics and gross rates from 100 studies conducted in forest, shrubland, grassland, and agricultural systems to answer the following questions: What factors appear to be the major drivers for production and consumption of inorganic $\mathrm{N}$ as measured by isotope dilution studies? Do rates or the relationships between drivers and rates differ among ecosystem types? Across a wide range of ecosystems, gross $\mathrm{N}$ mineralization is positively correlated with microbial biomass and soil $\mathrm{C}$ and $\mathrm{N}$ concentrations, while soil $\mathrm{C}: \mathrm{N}$ ratio exerts a negative effect on $\mathrm{N}$ mineralization only after adjusting for differences in soil C. Nitrification is a log-linear function of $\mathrm{N}$ mineralization, increasing rapidly at low mineralization rates but changing only slightly at high mineralization rates. In contrast, $\mathrm{NH}_{4}{ }^{+}$assimilation by soil microbes increases nearly linearly over the full range of mineralization rates. As a result, nitrification is proportionately more important as a fate for $\mathrm{NH}_{4}{ }^{+}$at low mineralization rates than at high mineralization rates. Gross nitrification rates show no relationship to soil $\mathrm{pH}$, with some of the fastest nitrification rates occurring below $\mathrm{pH} 5$ in soils with high $\mathrm{N}$ mineralization rates. Differences in soil organic matter (SOM) composition and concentration among ecosystem types influence the production and fate of mineralized N. Soil organic matter from grasslands appears to be inherently more productive of ammonium than SOM from wooded sites, and SOM from deciduous forests is more so than SOM in coniferous forests, but differences appear to result primarily from differing $\mathrm{C}: \mathrm{N}$ ratios of organic matter. Because of the central importance of SOM characteristics and concentrations in regulating rates, soil organic matter depletion in agricultural systems appears to be an important determinant of gross process rates and the proportion of $\mathrm{NH}_{4}{ }^{+}$that is nitrified. Addition of ${ }^{15} \mathrm{~N}$ appears to stimulate $\mathrm{NH}_{4}{ }^{+}$ consumption more than $\mathrm{NO}_{3}^{-}$consumption processes; however, the magnitude of the stimulation may provide useful information regarding the factors limiting microbial $\mathrm{N}$ transformations.
\end{abstract}

Key words: ammonium; $N$ assimilation; $N$ immobilization; ${ }^{15} N$ isotope dilution; $N$ mineralization, nitrate; nitrification; soil carbon; soil nitrogen; soil organic matter; soil pH.

\section{INTRODUCTION}

Determination of soil $\mathrm{N}$ mineralization and nitrification rates has long been a preoccupation for soil scientists and ecologists as they seek to understand the controls on terrestrial productivity, nutrient loss, and

Manuscript received 22 June 2004; revised 28 September 2004; accepted 29 September 2004. Corresponding Editor: P. M. Groffman

${ }^{4}$ E-mail: mary.stuart.booth@gmail.com microbial function (Schimel and Bennett 2004). Various methods exist for the determination of net mineralization and nitrification, but net rates may be a poor approximation of the real status of $\mathrm{N}$ cycling in soils (Davidson et al. 1991, Hart et al. 1994). Isotope dilution studies are increasingly reported in the soils and ecology literature as a means of measuring the gross rates of $\mathrm{N}$ mineralization, nitrification, and inorganic $\mathrm{N}$ assimilation in soils. The technique entails addition of ${ }^{15} \mathrm{~N}$ to label the pool of $\mathrm{NH}_{4}{ }^{+}$or $\mathrm{NO}_{3}{ }^{-}$in the soil. Newly 
produced $\mathrm{NH}_{4}{ }^{+}$or $\mathrm{NO}_{3}{ }^{-}$"dilutes" the ${ }^{15} \mathrm{~N}$ pool with ${ }^{14} \mathrm{~N}$, while consumptive processes are assumed to draw upon ${ }^{14} \mathrm{~N}$ and ${ }^{15} \mathrm{~N}$ alike and produce no change in isotopic enrichment. Because production rates are estimated with $\mathrm{N}$ additions to the product pool $\left({ }^{15} \mathrm{NH}_{4}{ }^{+}\right.$for mineralization, ${ }^{15} \mathrm{NO}_{3}{ }^{-}$for nitrification) they are believed to be unstimulated; however, consumption rates may be stimulated due to the addition of substrate ( $\mathrm{Da}-$ vidson et al. 1991).

It has been 50 years since the publication of Kirkham and Bartholomew's landmark 1954 paper that developed the theory and equations for estimating gross rates of $\mathrm{N}$-cycling processes based on isotope movement through soils. There now exists an abundance of published studies that have utilized this and related isotope pool dilution techniques, permitting a synthetic analysis of factors influencing gross $\mathrm{N}$ mineralization, nitrification, and inorganic $\mathrm{N}$ consumption rates in soils across a wide range of ecosystems. The three major assumptions of the Kirkham and Bartholomew model-that microbes do not discriminate between ${ }^{14} \mathrm{~N}$ and ${ }^{15} \mathrm{~N}$; that gross rates remain constant throughout the assay; and that no significant recycling of labeled $\mathrm{N}$ into the substrate pool occurs-are probably violated in certain instances. Nonetheless, the isotope dilution approach still remains the most accessible means for determining gross rates. Our objective in this paper is to assess what new insights isotope dilution studies can contribute to biogeochemical theory and whether the results are consistent with what has been determined by other means about biogeochemical $\mathrm{N}$ cycling. Using isotope dilution data on gross $\mathrm{N}$ cycling rates from published studies, we investigated two general questions. First, what factors appear to be the major drivers for production and consumption of $\mathrm{NH}_{4}{ }^{+}$and $\mathrm{NO}_{3}{ }^{-}$? And second, do rates and the relationships between drivers and rates differ among various types of ecosystems? Throughout the following discussion, "N mineralization," “nitrification," “consumption," and "assimilation" refer to the gross rates rather than net rates of these processes. Assimilation is considered synonymous with immobilization, and consumption is the sum of all consumption rates (e.g., $\mathrm{NH}_{4}{ }^{+}$consumption equals $\mathrm{NH}_{4}{ }^{+}$assimilation plus nitrification). Rates of gaseous loss (i.e., $\mathrm{NH}_{3}$ volatilization, denitrification, NO emission) are rarely reported in conjunction with isotope dilution rate estimates, and thus for the purposes of this paper, we assumed that these losses represented insignificant portions of consumption rates.

As the ultimate source of inorganic $\mathrm{N}$, the organic $\mathrm{N}$ pool size should be of primary importance for mineralization. However, the production of inorganic $\mathrm{N}$ may also be a function of the size and activity of the microbial biomass (Bengtsson et al. 2003) and exoenzyme production (Schimel and Weintraub 2003), as well as inorganic $\mathrm{N}$ excretion resulting from mesofaunal predation on microbes (Clarholm 1985, Myrold 1998). To the extent that the microbial biomass is a relatively constant proportion of soil carbon (C) (Anderson and Domsch 1989, Smith and Paul 1990, Zak et al. 1994), both microbial biomass and the $\mathrm{N}$ mineralization rate should increase with soil organic matter (SOM) concentration. However, SOM “quality," defined as the ease with which SOM can be degraded, should also influence inorganic $\mathrm{N}$ production.

Soil $\mathrm{C}$ and $\mathrm{N}$ concentration do appear to be effective predictors of mineralization. In an analysis of controls on gross mineralization in soils across a precipitation gradient in the western United States, Barrett and Burke (2000) found soil C was significantly related to gross mineralization, and in a test of various correlates of mineralization in 12 Australian soils, Wang et al. (2001) found a strong linear relationship between total soil $\mathrm{N}$ and gross mineralization (none of these data have been included in this review because soil characteristics could not be paired with rate data in either study). Soil $\mathrm{C}: \mathrm{N}$ ratio can serve as an estimate of the $\mathrm{N}$ yield per unit of SOM degraded, and as such, increasing soil $\mathrm{C}: \mathrm{N}$ ratios should exert a negative influence on mineralization rates, as has been reported by Hart et al. (1994) and Mack and D'Antonio (2003). This tendency could either be counterbalanced or exacerbated, however, depending on soil age and the degree of microbial processing that has occurred. Decomposition and $\mathrm{N}$ mineralization may proceed differently in mineral soils and organic layers comprised of younger SOM (Scott et al. 1998). In soils, $C: N$ ratio tends to decline as microbial processing proceeds (Hirobe et al. 2003), suggesting that while the "yield" of $\mathrm{N}$ per $\mathrm{C}$ mineralized may increase as the $\mathrm{C}: \mathrm{N}$ ratio falls, the overall palatability of SOM to microbes may concurrently decrease. In young, unprocessed fractions of SOM, such as in forest leaf litter, a high $\mathrm{C}: \mathrm{N}$ ratio may correspond to high concentrations of recalcitrant compounds that exert a negative influence on mineralization. However, a prediction of decreased $\mathrm{N}$ yield per unit SOM mineralized at higher $\mathrm{C}: \mathrm{N}$ ratios gives a similar result, rendering interpretation difficult. Further complicating the picture, Berg (2000) describes a nonlinear relationship between $\mathrm{N}$ concentration and litter decomposition in which litter $\mathrm{N}$ concentration is initially associated positively with decomposition rates, but has a negative effect as decomposition proceeds and lignin concentration in the remaining material increases.

Once produced, there are two main fates for $\mathrm{NH}_{4}{ }^{+}$ in the plant-free environment of a pool dilution assay: assimilation by microorganisms or oxidation to $\mathrm{NO}_{3}^{-}$ by nitrifiers. Controls on inorganic $\mathrm{N}$ assimilation might be expected to be similar to those on mineralization, because the microbial biomass as a whole is responsible for both the release and immobilization of nutrients. However, while soil organic $\mathrm{N}$ should be the main controller of mineralization rates, soil $\mathrm{C}$ would be expected to mediate microbial $\mathrm{N}$ assimilation. $\mathrm{Ni}$ trification should be a simple function of the amount of $\mathrm{NH}_{4}{ }^{+}$supplied by mineralization (Myrold 1998); for 
instance, Hart et al. (1997) found a strong linear relationship between nitrification and mineralization in forest soils of the Pacific Northwest. However, if microbial assimilation preempts $\mathrm{NH}_{4}{ }^{+}$uptake by nitrifiers (Hart et al. 1994) or the $\mathrm{NH}_{4}{ }^{+}$supply declines below some minimum threshold, nitrification may cease (Hart et al. 1994, Myrold 1998, Schimel and Bennett 2004). Additionally, soil organic matter composition may influence the balance between $\mathrm{NH}_{4}{ }^{+}$acquisition by heterotrophs and nitrifiers. In some systems, net nitrification (Compton and Boone 2000, Persson et al. 2000, Hirobe et al. 2003) and $\mathrm{NO}_{3}{ }^{-}$loss (Dise et al. 1998, Gundersen et al. 1998, Lovett et al. 2002) have been found to vary inversely with soil $\mathrm{C}: \mathrm{N}$ ratio, suggesting that increasing soil $\mathrm{C}: \mathrm{N}$ ratios may promote $\mathrm{NO}_{3}{ }^{-}$assimilation or suppress $\mathrm{NO}_{3}{ }^{-}$production.

\section{METHODS}

We examined relationships between gross $\mathrm{N}$ transformation rates and other soil characteristics, as well as relationships among rates, using regression analyses on data from 100 studies that reported results from isotope dilution assays on nearly 300 different organic and mineral soil materials from a wide range of ecosystems. We compiled data on soil characteristics $(\mathrm{pH}$, soil $\mathrm{C}$ and $\mathrm{N}$ concentrations, $\mathrm{C}: \mathrm{N}$, extractable $\mathrm{NH}_{4}^{+}$ and $\mathrm{NO}_{3}{ }^{-}$, and where provided, soil respiration rates and microbial $\mathrm{C}$ and $\mathrm{N}$ ) and matched these with process data $\left(\mathrm{N}\right.$ mineralization, $\mathrm{NH}_{4}{ }^{+}$consumption, $\mathrm{NH}_{4}{ }^{+}$assimilation, nitrification, $\mathrm{NO}_{3}{ }^{-}$assimilation, and where provided, net mineralization and net nitrification as determined by incubation of soils to which no ${ }^{15} \mathrm{~N}$ was added). Where $\mathrm{N}$ mineralization, $\mathrm{NH}_{4}{ }^{+}$consumption, and nitrification data were reported, $\mathrm{NH}_{4}{ }^{+}$assimilation was calculated as $\mathrm{NH}_{4}{ }^{+}$consumption minus nitrification (Davidson et al. 1991). Three additional variables were calculated and included in the analysis. The relative importance of nitrification and assimilation as consumptive fates can be estimated by their ratio (Aber 1992, Goulding et al. 1998, Murphy et al. 2001, Stockdale et al. 2002). Similarly, the ratio of nitrification : mineralization is another index of the nitrifying capacity of a soil, which tends to be highly correlated with the nitrification : assimilation ratio because of the covariance of assimilation and mineralization. The third calculated variable was the total $\mathrm{N}$ turnover rate, calculated as the mineralization rate divided by total soil N.

Study location was coded hierarchically with three levels: "climate," "vegetation type," and "growth form." Climate was coded as temperate, tropical, semiarid, or arctic/montane, with the recognition that local variation in climate makes these categories somewhat arbitrary. Vegetation type was coded as woodland (including forest, heath, and shrub sites), grassland (including meadows with a graminoid component and pastures), or agricultural (including only tilled soils). The vegetation type "woodland" included the growth forms of deciduous, coniferous, or N-fixing (in tropical systems, the "deciduous" category included broadleaf evergreen); the vegetation type "grassland" included the growth forms of perennial grass, annual grass, and meadow. Other variables included soil treatment ("intact" incubations, where ${ }^{15} \mathrm{~N}$ is introduced by needle into intact cores, minimizing disturbance, or "sieved"); soil type (organic or mineral soil material, i.e., taken from the humus layer or below it); and fertilization status (unfertilized controls or amended with organic or inorganic fertilizer). For mineral soils, data were restricted to samples collected from the top 10$15 \mathrm{~cm}$ of soil. The length of incubation was recorded. Data was read from tables or graphs, with unit conversions made as appropriate. When data was expressed as milligrams of $\mathrm{N}$ per square meter per day and bulk density values were given, data was converted to milligrams of $\mathrm{N}$ per kilogram per day. When bulk density was not given, data expressed as milligrams of $\mathrm{N}$ per square meter per day were included in the analysis of the nitrification : mineralization and nitrification : assimilation ratios, but not in other analyses.

We included as many references in the review as possible. To avoid overrepresentation of certain studies, however, only data collected at peak growing season were used from studies that were repeated through time at the same site. For studies in which soils were collected and incubated over several weeks or months in the laboratory, only the rates determined closest to the time of soil collection were included. Studies reporting gross rates that were less than or equal to net rates were excluded because negative gross rates cannot occur and because negative or zero values could not be log transformed, which was necessary to eliminate heteroscedasticity. In most cases, analyses were confined to data from unfertilized soils. However, because there were relatively few studies that reported microbial biomass and respiration, data from studies conducted in fertilized soils were included in these analyses. Data from fertilized soils were also used in analyses examining agricultural systems, most of which were assumed to have received $\mathrm{N}$ inputs at some point, even if not explicitly stated in the study. Where soil texture or organic matter content was not specified, soils were assumed to be from mineral soil horizons. Data from both mineral and organic soil layers were used in the analysis of large-scale patterns, but some of the comparisons among ecosystems were confined to mineral soil data. Analysis of gross rates determined simultaneously in sieved and intact cores (Stark 1991) suggests that sieving affects process rates; however, except where noted, measurements made using both sieved and intact soils were included in analyses.

All analyses were conducted using SYSTAT version 6.1 (SPSS 1996). All data except $\mathrm{pH}$ were $\log _{10}$ transformed prior to statistical analyses to eliminate heteroscedasticity. Because data included in the study were collected using different variations on the isotope

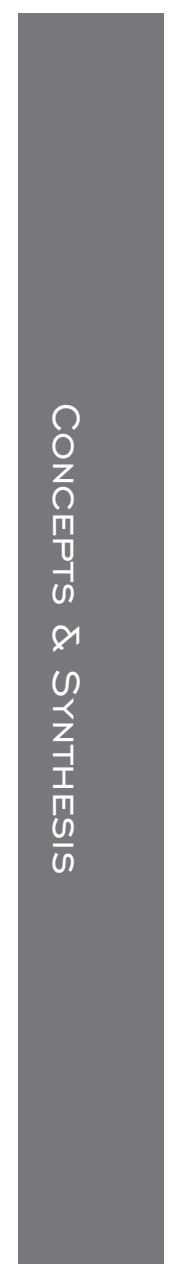


TABLE 1. $\quad R^{2}$ values for regressions of log-transformed microbial biomass C, microbial biomass $\mathrm{N}$, and soil respiration on $\mathrm{C}, \mathrm{N}$, and $\mathrm{C}: \mathrm{N}$ ratio of soils (with number of cases in parentheses).

\begin{tabular}{|c|c|c|c|c|c|}
\hline Soil property & Soil C & Soil N & $\mathrm{C}: \mathrm{N}$ & Microbial C & Microbial N \\
\hline Microbial C & $\begin{array}{l}0.60 * * \\
(41)\end{array}$ & $\begin{array}{l}0.65 * * * \\
(50)\end{array}$ & $\begin{array}{c}0.01 \\
(42)\end{array}$ & & \\
\hline Microbial N & $\begin{array}{l}0.30 * * * \\
(46)\end{array}$ & $\begin{array}{l}0.19 * * \\
(48)\end{array}$ & $\begin{array}{c}0.005 \\
(43)\end{array}$ & & \\
\hline Respiration & $\begin{array}{l}0.44 * * * \\
(32)\end{array}$ & $\begin{array}{c}0.002 \\
(44)\end{array}$ & $\begin{array}{c}0.11 * \\
(37)\end{array}$ & $\begin{array}{l}0.76 * * * \\
(35)\end{array}$ & $\begin{array}{l}0.66 * * * \\
(30)\end{array}$ \\
\hline
\end{tabular}

$* P \leq 0.05 ; * * P \leq 0.005 ; * * * P \leq 0.0005$.

dilution protocol, an outlier deletion policy was employed that excluded points outside the $99 \%$ confidence intervals from analyses. We used three main approaches to analyze the data. Regression analysis was used to analyze coarse-scale patterns in the data, such as between soil characteristics and gross rates. Analysis of variance was used to compare mean rates in different ecosystem types. Finally, analysis of covariance (ANCOVA) was used to determine whether relationships between characteristics and rates differed among ecosystem types. In all cases, $P$ values reported are for main effects, but where multiple means are reported as differing significantly, it can be assumed that $P$ values for Tukey multiple comparisons tests were $<0.05$.

We compared soil properties and process rates among categories using different subsets of the data. We compared agricultural, grassland, and woodland systems using only mineral soil, coniferous and deciduous systems using both mineral and organic soil layers from woodland soils, and climate effects using only mineral soil from woodland systems. We isolated two further subsets of data to address specific questions. One group of studies permitted comparison of gross rates (with incubation times of 24-48 h) with net rates in soils to which no ${ }^{15} \mathrm{~N}$ was added (incubated for 7 , 14, or 28-30 d; studies with longer incubation times were not included). We used a second group of studies from grassland and agricultural systems to examine the effect of fertilization on gross rates. All of these studies included fertilized and control treatments, with fertilization from either inorganic amendments or organic amendments, such as manure, applied historically or for the purposes of the study at hand (though there was no way to ascertain whether control treatments may have been fertilized at some time in the past). We designated values as being from "fertilized" or "control" soils and compared data for the two treatments using paired $t$ tests.

\section{A final caveat about the data}

Every study in the review included $\mathrm{N}$ mineralization data, nitrification data, or both, but not every study included data on soil $\mathrm{C}, \mathrm{N}$, or other characteristics. Thus, different analyses were conducted using overlapping, but not identical data sets. The low proportion of studies reporting a full data set on gross rates and soil characteristics precluded the use of principal com- ponents analysis or multiple regression except where both soil $\mathrm{C}$ concentration and $\mathrm{C}: \mathrm{N}$ ratio were regressed against mineralization, $\mathrm{NH}_{4}^{+}$assimilation, and $\mathrm{NO}_{3}^{-}$ assimilation. However, the single-factor regression approach used here has the potential to highlight major relationships in the data set.

\section{RESULTS}

\section{Controls on microbial biomass and respiration}

In the relatively few studies that reported microbial biomass values, microbial biomass $\mathrm{C}$ and $\mathrm{N}$ were significantly and positively correlated with soil $\mathrm{C}$ and $\mathrm{N}$ (Table 1). There was a significant negative relationship between microbial biomass $\mathrm{C}$ and soil $\mathrm{C}: \mathrm{N}$ ratio when soil $\mathrm{C}: \mathrm{N}$ ratio was regressed in conjunction with soil $\mathrm{C}$ (Table 2). $\mathrm{CO}_{2}$ flux was significantly and positively related to soil $\mathrm{C}$, soil $\mathrm{C}: \mathrm{N}$ ratio, and microbial biomass $\mathrm{C}$ and $\mathrm{N}$.

\section{Controls on $N$ mineralization}

Gross $\mathrm{N}$ mineralization was positively correlated with total soil $\mathrm{N}$ concentration (Fig. 1, Table 3), reflecting the basic importance of substrate availability

TABLE 2. Relationships of microbial biomass C (as mg C/ $\mathrm{g}$ soil), and mineralization, $\mathrm{NH}_{4}{ }^{+}$assimilation, and $\mathrm{NO}_{3}{ }^{-}$ assimilation (as $\mathrm{mg} \mathrm{N} \cdot \mathrm{kg}^{-1}$ soil $\cdot \mathrm{d}^{-1}$ ) to soil $\mathrm{C}$ concentration (g C/kg soil) and soil $\mathrm{C}: \mathrm{N}$ ratio for the combined data set of mineral and organic soils.

\begin{tabular}{cccc}
\hline \hline $\begin{array}{c}\text { Model and } \\
\text { measure }\end{array}$ & Coefficient & $t$ & $P$ \\
\hline Microbial biomass $\mathrm{C}\left(F_{2,38}=\right.$ & & \\
Intercept & 0.528 & $\left.P<0.00001, R^{2}=0.67\right)$ \\
Log C & 0.96 & 1.93 & 0.06 \\
Log C:N & -0.95 & -3.79 & 0.00001 \\
Mineralization & $\left(F_{2,127}=66.52, P\right.$ & 0.0005 \\
Intercept & 1.31 & 0.00001, & $\left.R^{2}=0.51\right)$ \\
Log C & 0.93 & 11.4 & $<0.00001$ \\
Log C:N & -1.1 & -4.94 & $<0.00001$ \\
$\mathrm{NH}_{4}{ }^{+}$assimilation & $\left(F_{2,71}=41.61, P<0.00001, R^{2}=0.54\right)$ \\
Intercept & 1.11 & 2.65 & 0.01 \\
Log C & 1.16 & 9.07 & $<0.00001$ \\
Log C:N & -1.08 & -3.04 & 0.003 \\
$\mathrm{NO}_{3}{ }^{-}$assimilation & $\left(F_{2,81}=12.67, P<0.00002, R^{2}=0.24\right)$ \\
Intercept & 0.272 & 0.78 & 0.44 \\
Log C & 0.568 & 4.98 & $<0.00001$ \\
Log C:N & -0.469 & -1.57 & 0.12 \\
\hline
\end{tabular}



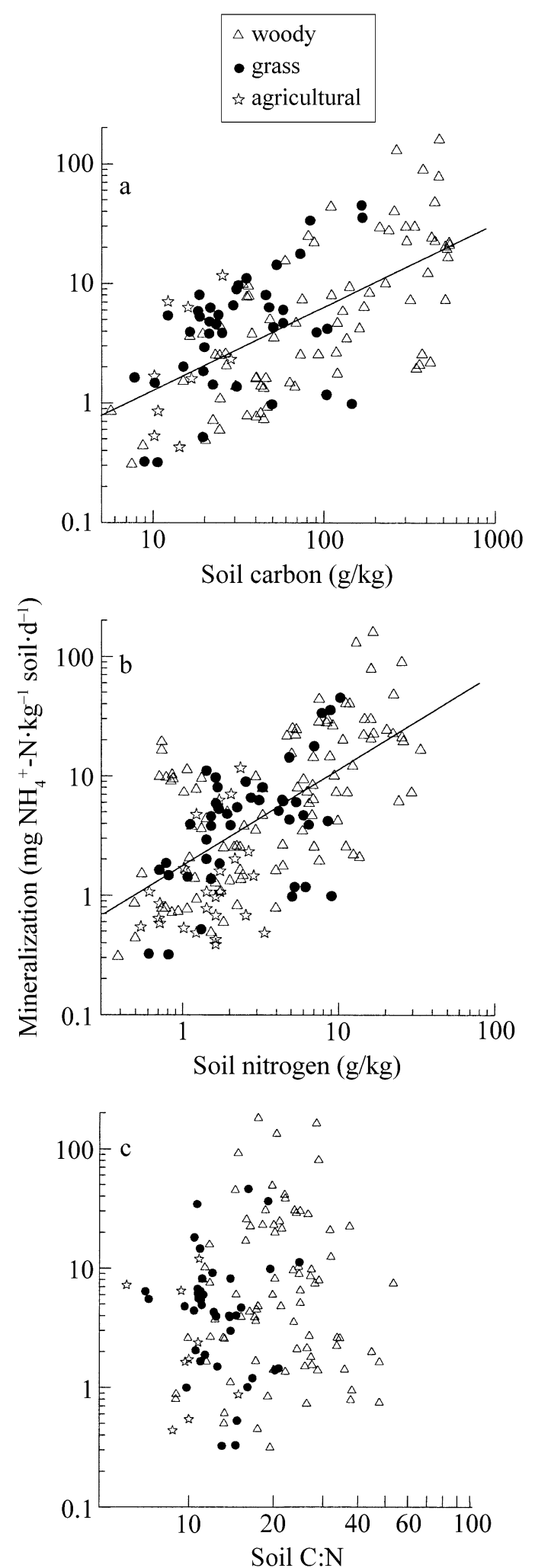

FIG. 1. Relationships of gross $\mathrm{N}$ mineralization to: (a) total carbon concentration, (b) total nitrogen concentration, and (c) $\mathrm{C}: \mathrm{N}$ ratio, in mineral and organic soil layers from agricultural, grassland, and woodland ecosystems. See Table 3 for regression equations and statistics. in regulating inorganic $\mathrm{N}$ production. The correlation between $\mathrm{N}$ mineralization and soil $\mathrm{C}$ was also strong, reflecting covariance between soil $\mathrm{C}$ and $\mathrm{N}$ concentrations. Microbial biomass $\mathrm{N}$ and $\mathrm{C}$ were also predictive (Table 3), but relatively few studies reported these values, making true evaluation problematic. As with microbial biomass, there was a significant negative relationship between soil $\mathrm{C}: \mathrm{N}$ ratio and mineralization when soil $\mathrm{C}: \mathrm{N}$ ratio was regressed in conjunction with soil C (Table 2), despite the general tendency for soil $\mathrm{C}: \mathrm{N}$ ratio to increase with soil $\mathrm{C}$ concentration (log $\mathrm{C}: \mathrm{N}=0.195 \times \log \mathrm{C}+0.88 ; P<0.0001, R^{2}=0.30$; $n=141$ ). The relationship between $\mathrm{N}$ mineralization and $\mathrm{C}: \mathrm{N}$ was equivalently strong in the subset of forest soil data (which contained the greatest range of soil $\mathrm{C}: \mathrm{N}$ values) as in the entire data set. Mineralization was found to increase with increasing soil gravimetric moisture content (Table 3), but since soil moisture content itself increased with soil $\mathrm{C}$ concentration (log soil moisture $=0.622 \times \log \mathrm{C}-1.53 ; P<0.0001, R^{2}=$ $0.58 ; n=75)$, it was not possible to separate the two factors.

\section{Controls on nitrification}

Nitrification was strongly dependent on $\mathrm{N}$ mineralization, with a linear relationship accounting for $\sim 32 \%$ of the variance in transformed nitrification data (Fig. 2, Table 3). Untransformed data were best described by a power function, where the proportion of $\mathrm{N}$ mineralized that was nitrified decreased as mineralization increased (at a mineralization rate of $1 \mathrm{mg} \mathrm{N} \cdot \mathrm{kg}^{-1}$ soil $\cdot \mathrm{d}^{-1}$ approximately $63 \%$ of $\mathrm{N}$ mineralized was nitrified; at a rate of $5 \mathrm{mg} \mathrm{N} \cdot \mathrm{kg}^{-1} \cdot \mathrm{d}^{-1}$ approximately $28 \%$ was nitrified; and at a rate of $10 \mathrm{mg} \mathrm{N} \cdot \mathrm{kg}^{-1} \mathrm{soil} \cdot \mathrm{d}^{-1}$ approximately $19 \%$ was nitrified). Nitrification rates were also related to extractable $\mathrm{NH}_{4}{ }^{+}$(Table 3). Soil C and $\mathrm{N}$ had less predictive power for nitrification than did mineralization, and soil $\mathrm{C}: \mathrm{N}$ ratio had none (Table 3 ). To a great extent, the relationships between nitrification and soil $\mathrm{C}$ and $\mathrm{N}$ concentrations were driven by the inclusion of data from organic soil material, which had the highest mineralization rates. The $\mathrm{pH}$ values in this data set ranged from 3.0 to 8.0, and there was a slightly significant negative relationship between nitrification and $\mathrm{pH}$, which was probably due to the highest nitrification rates being in organic soils, which tended to have lower $\mathrm{pH}$ (Fig. 3a, Table 3). There was a negative relationship between soil $\mathrm{C}$ concentration and $\mathrm{pH}$ (Fig. $3 \mathrm{~b} ; \mathrm{pH}=-1.162 \log \mathrm{C}+7.50 ; R^{2}=$ $0.28 ; P<0.0001 ; n=122)$.

\section{Controls on uptake fates of inorganic $N$}

Extractable $\mathrm{NH}_{4}{ }^{+}$and $\mathrm{NO}_{3}{ }^{-}$were positively related to soil $\mathrm{C}$ in transformed data and were of the same magnitude as daily production and assimilation rates at any given soil C concentration (Fig. 4a, b; Table 3). The mean residence times for $\mathrm{NH}_{4}{ }^{+}$and $\mathrm{NO}_{3}{ }^{-}$(calculated as the extractable pool divided by the produc- 
TABLE 3. Single-factor regression equations for relationships in transformed soils data.

\begin{tabular}{|c|c|c|c|c|c|}
\hline Variable/process & Equation & $N \ddagger$ & $\begin{array}{c}\text { No. } \\
\text { outliers } \\
\text { deleted }\end{array}$ & $P$ & $R^{2}$ \\
\hline \multicolumn{6}{|l|}{ Mineralization (min) } \\
\hline Soil C & $\log \min =0.706 \times \log C+0.123$ & 130 & & $<0.00001$ & 0.42 \\
\hline Soil N & $\log \min =0.852 \times \log N+1.076$ & 173 & & $<0.0001$ & 0.42 \\
\hline Soil C:N & $\log \min =0.370 \times \log \mathrm{C}: \mathrm{N}+0.236$ & 135 & & 0.16 & 0.01 \\
\hline Microbial biomass $\mathrm{N}$ & $\log \min =0.540 \times \log \mathrm{mb}-\mathrm{N}+1.08$ & 59 & & $<0.0001$ & 0.27 \\
\hline Microbial biomass C & $\log \min =0.580 \times \log \mathrm{mb}-\mathrm{C}+0.741$ & 53 & & $<0.0001$ & 0.27 \\
\hline Respiration & $\log \min =0.422 \times \log$ resp -0.026 & 60 & & 0.00005 & 0.25 \\
\hline Moisture content & $\log \min =0.555 \times \log \mathrm{mc}+0.980$ & 87 & & $<0.0001$ & 0.30 \\
\hline \multicolumn{6}{|l|}{$\mathrm{NH}_{4}^{+}$consumption (cons) } \\
\hline Mineralization & $\log \operatorname{cons}=0.900 \times \log \min +0.105$ & 173 & 2 & $<0.0001$ & 0.87 \\
\hline Microbial biomass $\mathrm{N}$ & $\log \operatorname{cons}=0.480 \times \log \mathrm{mb}-\mathrm{N}+1.102$ & 36 & & 0.003 & 0.23 \\
\hline \multicolumn{6}{|l|}{$\mathrm{NH}_{4}{ }^{+}$assimilation (assim) } \\
\hline Mineralization & $\log \mathrm{NH}_{4}{ }^{+}$assim $=1.02 \times \log \min -0.153$ & 126 & 2 & $<0.0001$ & 0.86 \\
\hline Microbial biomass $\mathrm{N}$ & $\log \mathrm{NH}_{4}^{+}$assim $=1.01 \times \log \mathrm{mb}-\mathrm{N}+1.67$ & 15 & & 0.002 & 0.52 \\
\hline Soil C & $\log \mathrm{NH}_{4}{ }^{+}$assim $=0.993 \times \log \mathrm{C}-0.121$ & 74 & 1 & $<0.0001$ & 0.48 \\
\hline \multicolumn{6}{|l|}{ Nitrification (nit) } \\
\hline Mineralization & $\log$ nit $=0.461 \times \log \min -0.195$ & 167 & 2 & $<0.0001$ & 0.32 \\
\hline Soil C & $\log$ nit $=0.469 \times \log C-0.210$ & 106 & 1 & $<0.00001$ & 0.21 \\
\hline Soil N & $\log$ nit $=0.543 \times \log N-0.411$ & 127 & 1 & $<0.0001$ & 0.24 \\
\hline Soil C:N & $\log$ nit $=0.192 \times \log C: N-0.086$ & 107 & 1 & 0.5 & 0.00 \\
\hline $\mathrm{pH}$ & $\log$ nit $=-0.089 \times \mathrm{pH}+0.628$ & 100 & 1 & 0.03 & 0.05 \\
\hline Extractable $\mathrm{NH}_{4}^{+}$ & $\log$ nit $=0.395 \times \log$ extr $\mathrm{NH}_{4}^{+}-0.196$ & 79 & 1 & $<0.0001$ & 0.18 \\
\hline \multicolumn{6}{|l|}{$\mathrm{NO}_{3}{ }^{-}$assimilation } \\
\hline Soil C & $\log \mathrm{NO}_{3}{ }^{-}$assim $=0.487 \times \log \mathrm{C}-0.259$ & 84 & 2 & $<0.0001$ & 0.22 \\
\hline Nitrification & $\log \mathrm{NO}_{3}-$ assim $=0.595 \times \log$ nit +0.093 & 108 & 2 & $<0.0001$ & 0.39 \\
\hline Mineralization & $\log \mathrm{NO}_{3}^{-}$assim $=0.480 \times \log \min -0.182$ & 101 & 1 & $<0.0001$ & 0.33 \\
\hline Microbial biomass $\mathrm{N}$ & $\log \mathrm{NO}_{3}^{-}$assim $=0.516 \times \log \mathrm{mb}-\mathrm{N}+0.571$ & 24 & & 0.0005 & 0.45 \\
\hline Extractable $\mathrm{NH}_{4}^{+}$ & $\log \mathrm{NO}_{3}^{-}$assim $=0.445 \times \log$ extr $\mathrm{NH}_{4}^{+}-0.184$ & 66 & & $<0.0001$ & 0.26 \\
\hline \multicolumn{6}{|l|}{ Extractable (extr) $\mathrm{NH}_{4}^{+}$} \\
\hline Mineralization & $\log$ extr $\mathrm{NH}_{4}{ }^{+}=0.664 \times \log \min +0.314$ & 104 & & $<0.0001$ & 0.40 \\
\hline Soil C & $\log$ extr $\mathrm{NH}_{4}^{+}=0.720 \times \log \mathrm{C}-0.477$ & 84 & & $<0.0001$ & 0.45 \\
\hline Soil N & $\log$ extr $\mathrm{NH}_{4}^{+}=0.798 \times \log \mathrm{N}+1.145$ & 92 & & $<0.0001$ & 0.40 \\
\hline Soil C:N & $\log$ extr $\mathrm{NH}_{4}^{+}=0.940 \times \log \mathrm{C}: \mathrm{N}-0.331$ & 84 & & 0.01 & 0.08 \\
\hline \multicolumn{6}{|l|}{ Extractable $\mathrm{NO}_{3}^{-}$} \\
\hline Mineralization & $\log$ extr $\mathrm{NO}_{3}{ }^{-}=0.459 \times \log \min -0.249$ & 96 & 1 & $<0.001$ & 0.14 \\
\hline Nitrification & $\log$ extr $\mathrm{NO}_{3}^{-}=0.718 \times \log$ nit +0.117 & 76 & 1 & $<0.0001$ & 0.3 \\
\hline Soil C & $\log$ extr $\mathrm{NO}_{3}^{-}=0.398 \times \log \mathrm{C}-0.164$ & 77 & & 0.005 & 0.1 \\
\hline Soil N & $\log$ extr $\mathrm{NO}_{3}^{-}=0.421 \times \log \mathrm{N}+0.258$ & 85 & & 0.01 & 0.08 \\
\hline Soil C:N & $\log$ extr $\mathrm{NO}_{3}^{-}=-0.356 \times \log \mathrm{C}: \mathrm{N}+0.600$ & 77 & & 0.43 & 0.01 \\
\hline
\end{tabular}

Notes: Data include values from both mineral and organic soil horizons. Units for rates are $\mathrm{mg} \mathrm{N} \cdot \mathrm{kg}^{-1}$ soil $\cdot \mathrm{d}^{-1}$; units for pools are $\mathrm{mg} \mathrm{N} / \mathrm{kg}$ soil, except for microbial biomass $\mathrm{C}$ and $\mathrm{N}$, which are $\mathrm{mg} / \mathrm{g}$ soil.

tion rate, under the assumption that in undisturbed conditions, pools are at steady state and production and consumption are equal) were not significantly different from a value of one day (using a one-tailed $t$ test on log-transformed data, $H_{0}$, mean $=0$; for $\mathrm{NH}_{4}{ }^{+}$, mean $=0.016, P=0.7$; for $\mathrm{NO}_{3}{ }^{-}$, mean $=0.009, P=0.88$ ). Mean residence time did not differ between $\mathrm{NH}_{4}{ }^{+}$and $\mathrm{NO}_{3}{ }^{-}(P=0.78)$. Extractable $\mathrm{NH}_{4}{ }^{+}$was also positively related to soil $\mathrm{N}$ concentration and soil $\mathrm{C}: \mathrm{N}$ ratio, while extractable $\mathrm{NO}_{3}{ }^{-}$showed a weak or no relationship with these variables (Table 3).

Microbial assimilation rates of both $\mathrm{NH}_{4}{ }^{+}$and $\mathrm{NO}_{3}{ }^{-}$ were positively and linearly related to production rates in both transformed and untransformed data. In untransformed data, $\mathrm{NH}_{4}{ }^{+}$consumption was approximately $113 \%$ of mineralization and $\mathrm{NH}_{4}{ }^{+}$assimilation was approximately $84 \%$ of mineralization, while $\mathrm{NO}_{3}^{-}$ assimilation was about $59 \%$ of nitrification. Assimilation rates of $\mathrm{NH}_{4}{ }^{+}$and $\mathrm{NO}_{3}{ }^{-}$were positively related to microbial biomass $\mathrm{N}$ and soil $\mathrm{C}$ (Fig. 4a, b; Table 3 ), but the slope of the relationship with soil $\mathrm{C}$ was greater for $\mathrm{NH}_{4}^{+}$than $\mathrm{NO}_{3}^{-}$(demonstrated by a significant interaction term indicating nonhomogeneity of slopes in ANCOVA). For $\mathrm{NO}_{3}{ }^{-}$assimilation only, there was an additional effect of soil treatment, so that at a given soil $\mathrm{C}$ concentration, $\mathrm{NO}_{3}{ }^{-}$assimilation was higher in assays that were conducted in intact, rather than sieved cores $(P=0.0001$ for soil treatment as the categorical variable in the ANCOVA of $\mathrm{NO}_{3}^{-}$assimilation on soil $\mathrm{C}$ concentration).

By itself, soil $\mathrm{C}: \mathrm{N}$ ratio had almost no relationship to $\mathrm{NH}_{4}{ }^{+}$or $\mathrm{NO}_{3}{ }^{-}$assimilation. However, in combination 


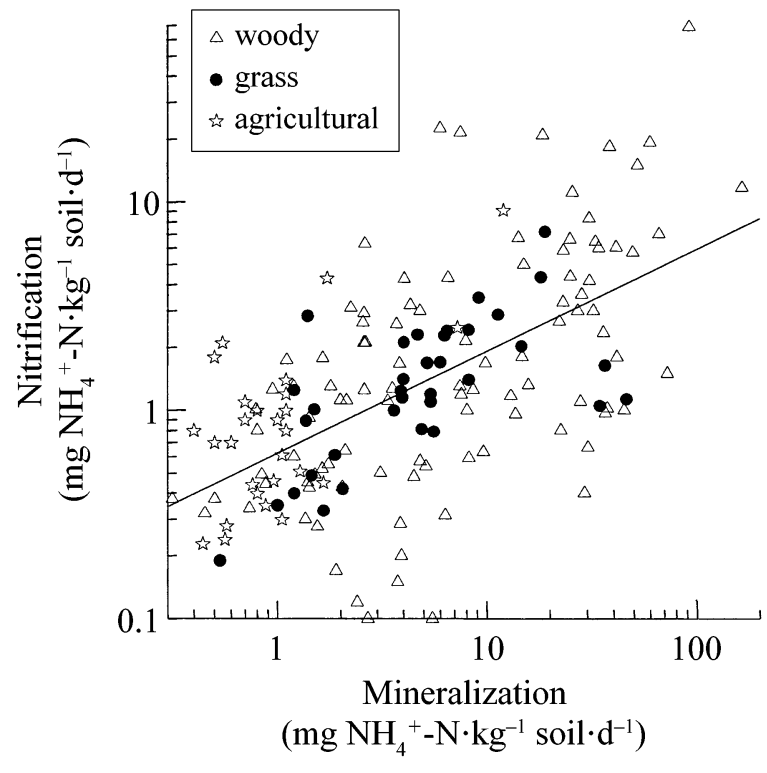

FIG. 2. Relationship of nitrification to $\mathrm{N}$ mineralization in mineral and organic soil layers from agricultural, grassland, and woodland ecosystems. See Table 3 for regression equations and statistics.

with soil $\mathrm{C}$, soil $\mathrm{C}: \mathrm{N}$ ratio showed a significant negative relationship with $\mathrm{NH}_{4}{ }^{+}$assimilation (Table 2). Nitrate assimilation was positively correlated with both $\mathrm{NH}_{4}{ }^{+}$ concentrations and gross $\mathrm{N}$ mineralization rates (Table 3 ), but expressed as a proportion of total assimilation, $\mathrm{NO}_{3}{ }^{-}$assimilation was a declining function of mineralization (Fig. 5a). When assimilation of $\mathrm{NH}_{4}{ }^{+}$or $\mathrm{NO}_{3}{ }^{-}$ was regressed against their respective extractable forms, there was a steeper and better defined relationship for $\mathrm{NH}_{4}{ }^{+}$than $\mathrm{NO}_{3}^{-}$(Fig. 5b) as demonstrated by a significant interaction term in the ANCOVA $(P<$ $0.0001)$.

Since intact plants are generally not present during pool dilution assays, microbial assimilation and nitrification are the main consumptive fates for $\mathrm{NH}_{4}{ }^{+}$. It was initially hypothesized that the balance between $\mathrm{NH}_{4}{ }^{+}$assimilation and nitrification depends on soil $\mathrm{C}: \mathrm{N}$ ratio, with nitrification being relatively less important at high soil $\mathrm{C}: \mathrm{N}$ ratios. However, soil $\mathrm{C}: \mathrm{N}$ had little predictive power for either variable, and none for their relative importance as expressed by the nitrification : assimilation ratio $\left(R^{2}=0.003 ; P=0.61\right)$. The relationship between $\mathrm{NH}_{4}^{+}$assimilation and nitrification was best illustrated by plotting the two consumptive fates against $\mathrm{NH}_{4}{ }^{+}$production (Fig. 6). The power function that describes the relationship of assimilation to mineralization is quite steep in untransformed data, but nitrification follows a more curvilinear power function, failing to keep pace with assimilation as mineralization rates increase. Rates of nitrification and assimilation are thus most similar at low mineralization rates $\left(<2 \mathrm{mg} \cdot \mathrm{kg}^{-1} \cdot \mathrm{d}^{-1}\right)$ and diverge rapidly with increasing mineralization rate. It should be kept in mind, however, that because of the way we have calculated microbial $\mathrm{NH}_{4}{ }^{+}$assimilation, it is likely to be overestimated, especially in soils where $\mathrm{NH}_{4}{ }^{+}$supply limits assimilation and nitrification rates. The overestimation occurs because assimilation is calculated as the difference between $\mathrm{NH}_{4}{ }^{+}$consumption from ${ }^{15} \mathrm{NH}_{4}{ }^{+}$dilution (where assimilation and nitrification may have been stimulated by addition of ${ }^{15} \mathrm{NH}_{4}{ }^{+}$) and nitrification from ${ }^{15} \mathrm{NO}_{3}{ }^{-}$dilution (where nitrification should not have been stimulated). If the overestimation of assimilation rates is greatest at low $\mathrm{N}$ mineralization rates, then
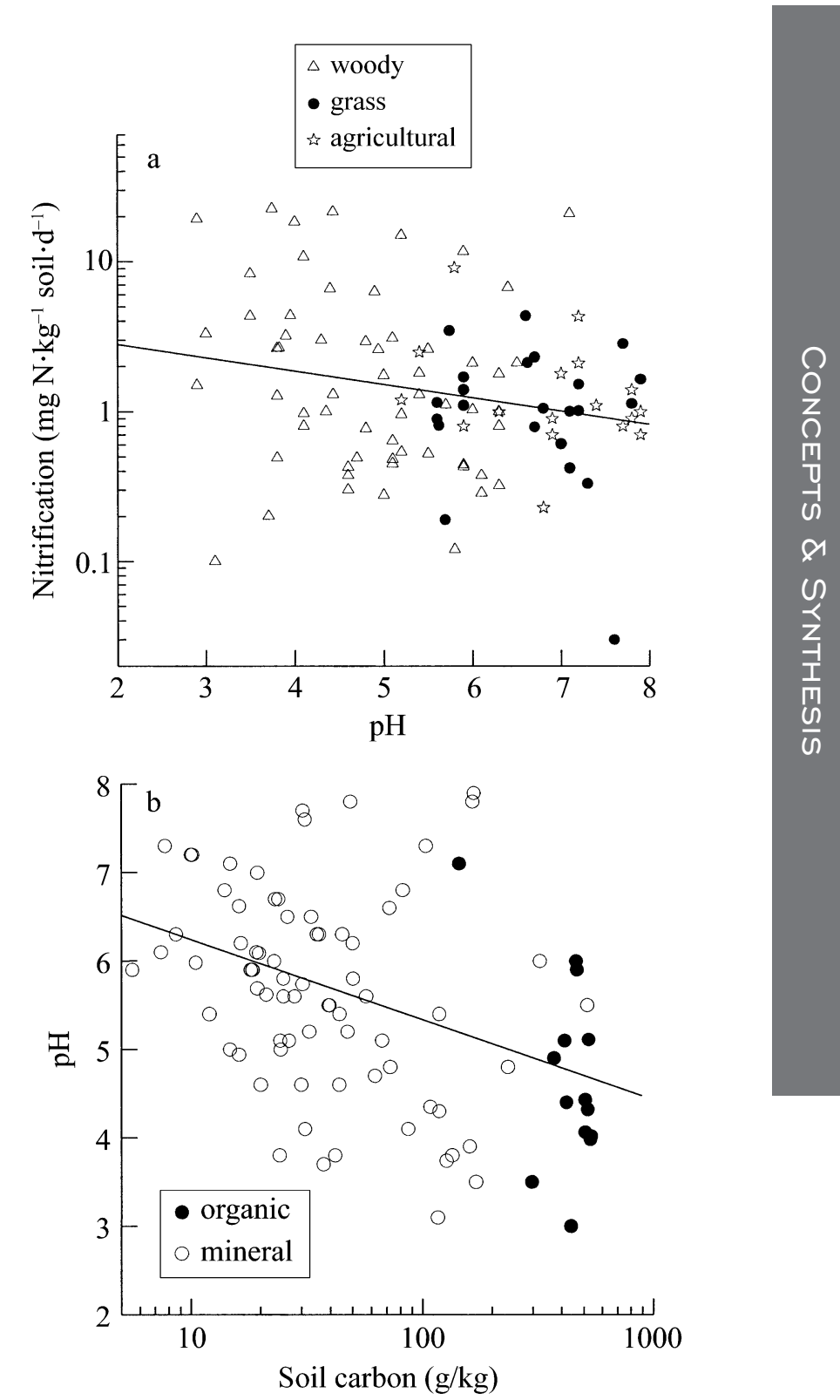

FIG. 3. (a) Relationship of nitrification to $\mathrm{pH}$ in mineral and organic soil layers from agricultural, grassland, and woodland ecosystems. See Table 3 for regression equations and statistics. (b) Relationship of $\mathrm{pH}$ to soil $\mathrm{C}$ concentration. 


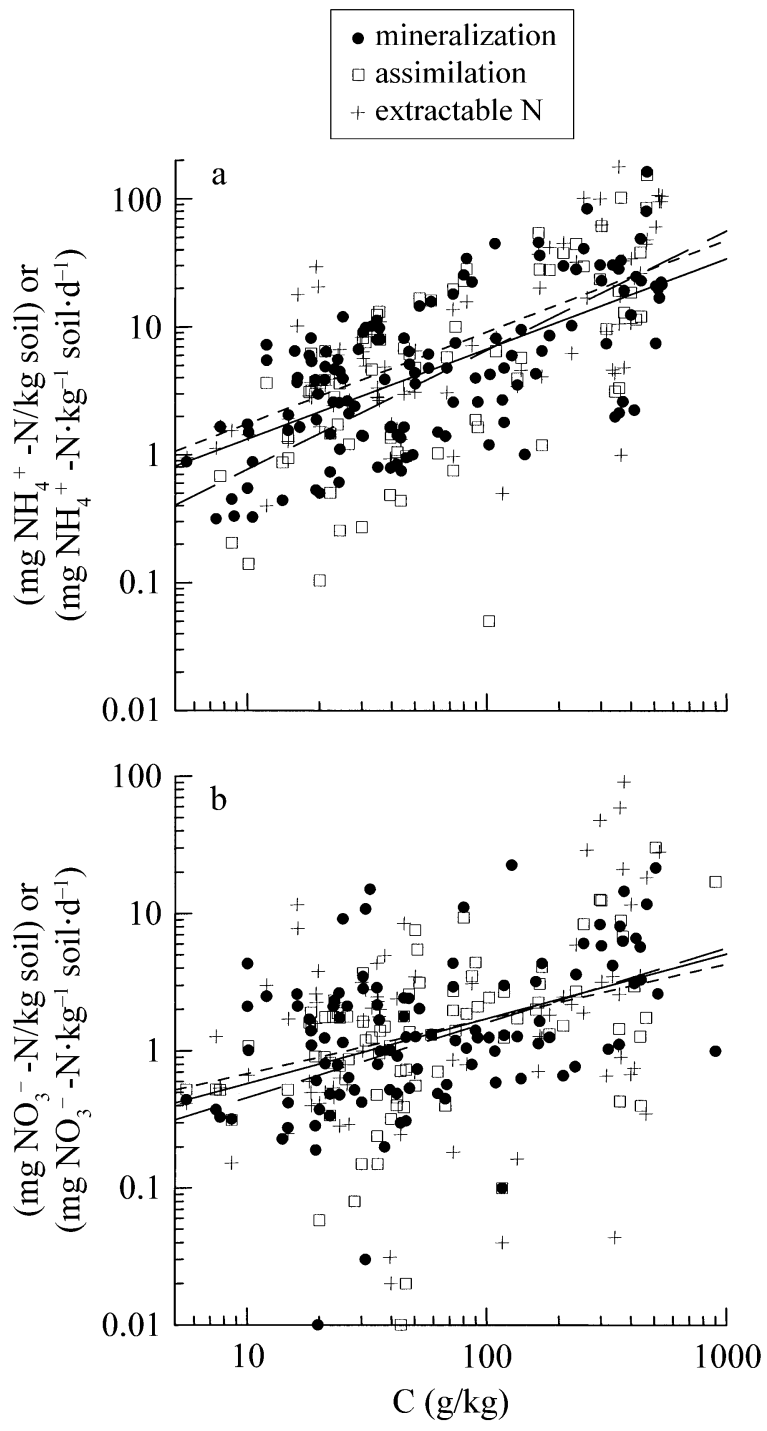

FIG. 4. For $\mathrm{NH}_{4}{ }^{+}$and $\mathrm{NO}_{3}{ }^{-}$, the relationships of production (circles, solid line), assimilation (squares, large dashed line), and extractable inorganic $\mathrm{N}$ (crosses, small dashed line) to soil C. See Table 3 for regression equations and statistics.

nitrification consumes an even greater proportion of $\mathrm{NH}_{4}{ }^{+}$in soils with low $\mathrm{N}$ mineralization rates.

\section{Relationship of net rates to gross rates}

For the several studies that examined net mineralization in unamended soils using incubations of 7,14 , or 28-30 d, there was a weak relationship between net $\mathrm{N}$ mineralization and gross $\mathrm{N}$ mineralization, which became clearer when the duration of the incubation was taken into account. For untransformed data, the slope of the net : gross rate relationship was steeper in soils that had been incubated $7 \mathrm{~d}$ than for those that had been incubated 14 or $30 \mathrm{~d}$ (Fig. 7). However, incubation time was confounded with vegetation type because almost all the 7-d incubations were conducted in grassland systems, whereas the longer incubations were conducted mostly in woody vegetation. In spite of this, the data suggest that the slope of the relationship between gross mineralization and net mineralization diminishes as incubation times increase. The relationship between net nitrification and gross nitrification also appeared to diminish with the length of the incubation. However, there were relatively few studies that reported net nitrification rates in samples not receiving ${ }^{15} \mathrm{~N}$, and thus the pattern was weaker.
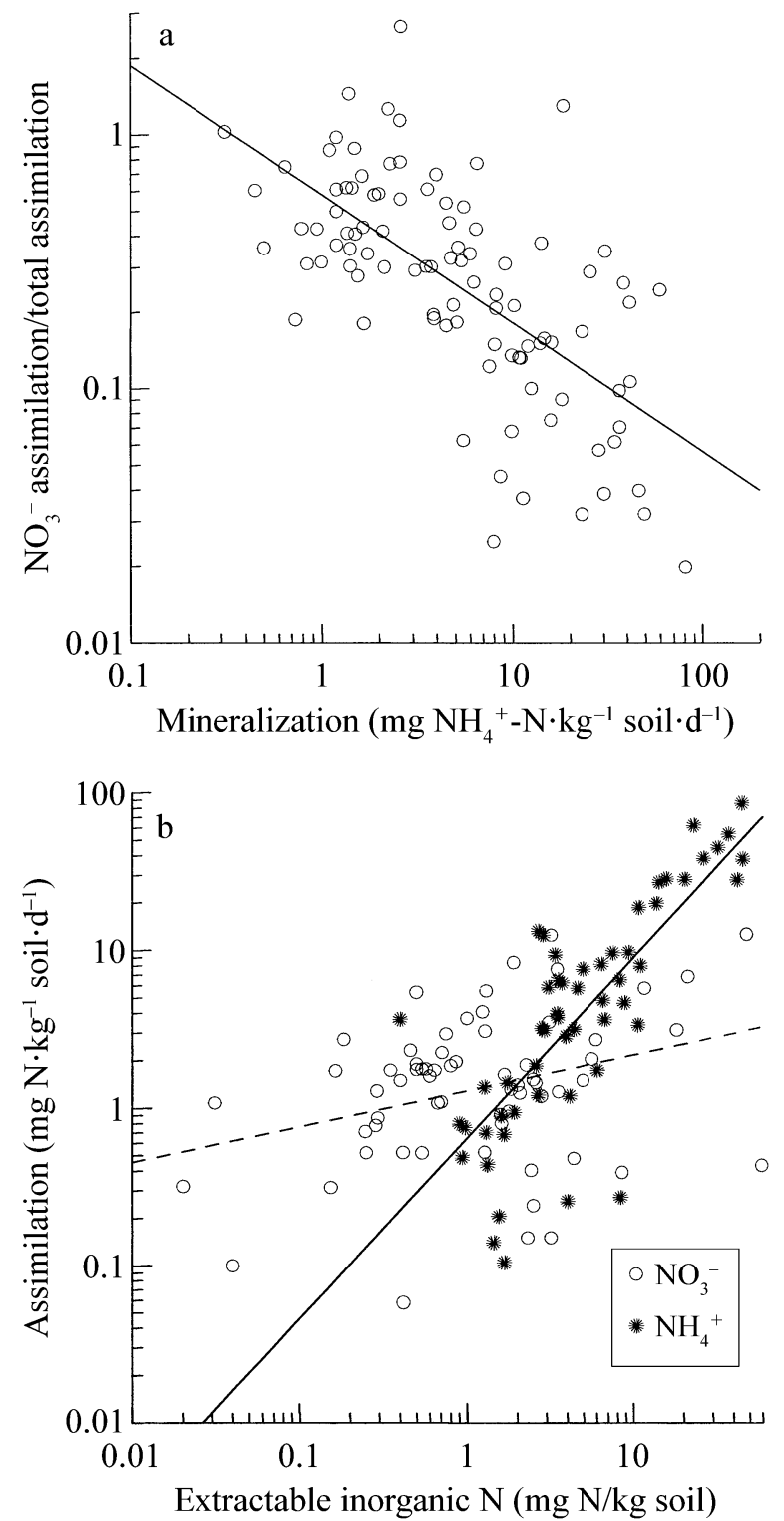

FIG. 5. (a) The relationship between the proportion of total assimilation comprised by $\mathrm{NO}_{3}{ }^{-}$assimilation and mineralization $\left[\log \left(\mathrm{NO}_{3}{ }^{-}\right.\right.$assimilation/total assimilation $)=$ $-0.51 \times \log$ mineralization $-0.23 ; n=96, R^{2}=0.43, P<$ 0.00001] and (b) the relationship between assimilation and inorganic $\mathrm{N}$ concentration (as $\mathrm{NH}_{4}{ }^{+}$or $\mathrm{NO}_{3}{ }^{-}$, respectively), in mineral and organic soil. 


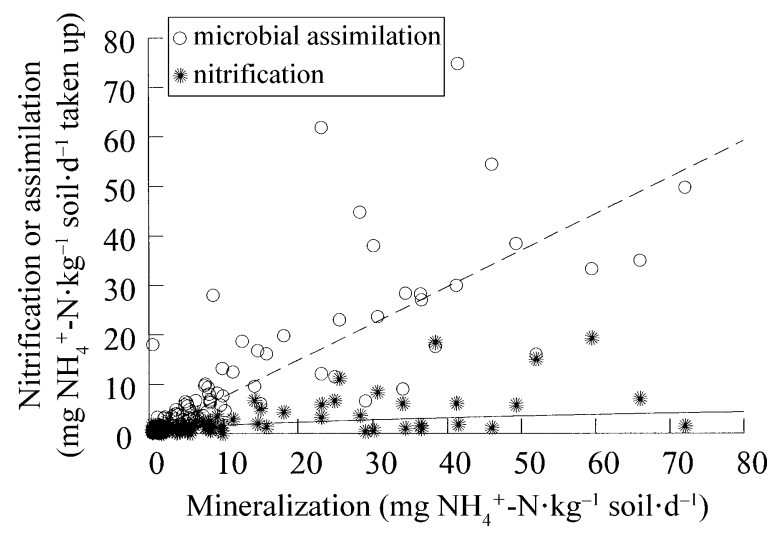

FIG. 6. Relationships of nitrification and microbial $\mathrm{NH}_{4}{ }^{+}$ assimilation to $\mathrm{N}$ mineralization in untransformed data Trendline equations: $\mathrm{NH}_{4}{ }^{+}$assimilation $=0.706 \times($ mineralization $)^{1.03}, R^{2}=0.86, P<0.001$; nitrification $=0.628 \times$ (mineralization) $)^{0.49}, R^{2}=0.36, P<0.001$.

\section{Fertilization effects on rates}

For the group of grassland and agricultural studies containing fertilized and control treatments, there was a notable absence of differences between the treatments, with no significant fertilization effect on $\mathrm{N}$ mineralization, $\mathrm{NH}_{4}{ }^{+}$consumption, $\mathrm{NH}_{4}{ }^{+}$assimilation, nitrification, $\mathrm{NO}_{3}{ }^{-}$assimilation, the nitrification : mineralization ratio, or the nitrification : assimilation ratio $(P>0.05$; paired $t$ test $)$.

\section{Soil properties and rates in agricultural, grassland, and woodland systems}

Statistical comparisons among vegetation types were confined to mineral soil material from temperate, semiarid, and arctic/montane regions, because we found very few grassland and no agricultural studies conducted in tropical systems. However, data from tropical systems are shown in Fig. 8 for purposes of visual comparison, and a separate statistical comparison of climates that included values from both mineral and organic soil material of semiarid, temperate, and tropical systems was conducted using the subset of woodland soils. Since it is the nature of agricultural systems to receive fertilization, data from fertilized and unfertilized agricultural soils alike were included in the comparison among agricultural, grassland, and woodland systems. Means reported in the text are for untransformed data and occur in the order of agricultural, grassland, and woodland systems.

Mineral soil $\mathrm{C}$ concentrations were lowest in agricultural systems and did not differ between grasslands and woodlands $(21.5,45.2$, and $51.6 \mathrm{~g} \mathrm{C} / \mathrm{kg}$ soil; $P=$ 0.0006; Fig. 8a). The mean soil $\mathrm{N}$ concentration in grasslands was significantly higher than in agricultural systems, but did not differ from that in woodlands (1.9, 3.9, and $3.7 \mathrm{~g} \mathrm{~N} / \mathrm{kg}$ soil; $P=0.024$; Fig. 8b). Soil $\mathrm{C}: \mathrm{N}$ ratio was higher in woodlands than grasslands or agricultural systems $(10.2,12.4$, and $21.2 ; P<0.0001$;
Fig. 8c). There was also a significant vegetation type effect in the ANCOVA of $\mathrm{C}: \mathrm{N}$ on soil $\mathrm{C}$, indicating that woodland soils had a higher $\mathrm{C}: \mathrm{N}$ ratio than grassland or agricultural soils, even at equivalent $\mathrm{C}$ concentrations $(P<0.0001)$. Relatively few studies reported microbial biomass, especially for agricultural systems, and while microbial biomass $\mathrm{C}$ and $\mathrm{N}$ in mineral soils tended to track soil $\mathrm{C}$ and $\mathrm{N}$ (Table 1), values in grassland soils were not significantly higher than in woodland soils (untransformed means for grassland and woodland soils, respectively: 1.13 and $1.07 \mathrm{mg}$ microbial $\mathrm{C} / \mathrm{g}$ soil, $P=0.26 ; 0.18$ and $0.14 \mathrm{mg} \mathrm{mi-}$ crobial N/g soil, $P=0.18$ ). There was no difference in mean microbial biomass $\mathrm{C}: \mathrm{N}$ ratios between grassland and woodland soils (5.10 and 5.54, respectively; $P=0.49)$. In grasslands and woodlands, respectively, microbial biomass $\mathrm{C}$ represented $4.53 \%$ and $1.42 \%$ of total $\mathrm{C}(P<0.001)$, and microbial biomass $\mathrm{N}$ represented $8.76 \%$ and $5.34 \%$ of total $\mathrm{N}(P=0.74)$. The difference in the mean residence time (MRT) for microbial biomass (calculated as microbial biomass N/ mineralization) between grasslands and woodlands was not significant (microbial MRT in grasslands, $33 \mathrm{~d}$; in woodlands, $66 \mathrm{~d} ; P=0.08$ ).

Nitrogen mineralization rates were highest in grasslands, intermediate in woodlands, and lowest in agricultural systems (1.76, 7.34, and 3.97 $\mathrm{mg} \mathrm{N} \cdot \mathrm{kg}^{-1}$ soil $\cdot \mathrm{d}^{-1} ; P<0.0001$; Fig. $\left.8 \mathrm{~d}\right)$. Ammonium consumption was also highest in grasslands $(P=$ 0.002 ), but did not differ significantly between grass-

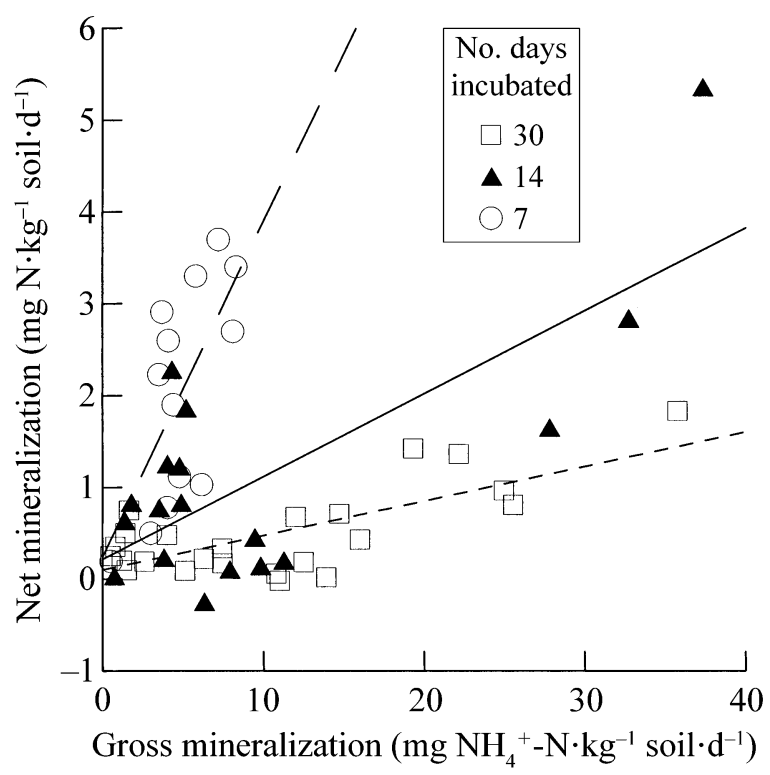

FIG. 7. The relationship between net and gross $\mathrm{N}$ mineralization rates for net mineralization studies with incubations of 7 (long dashed line), 14 (solid line), or 28-30 d (short dashed line). Gross rates incubations lasted 24, 48, or $120 \mathrm{~h}$. Because incubation period for net mineralization was partially confounded with vegetation type, slopes were not statistically compared. 

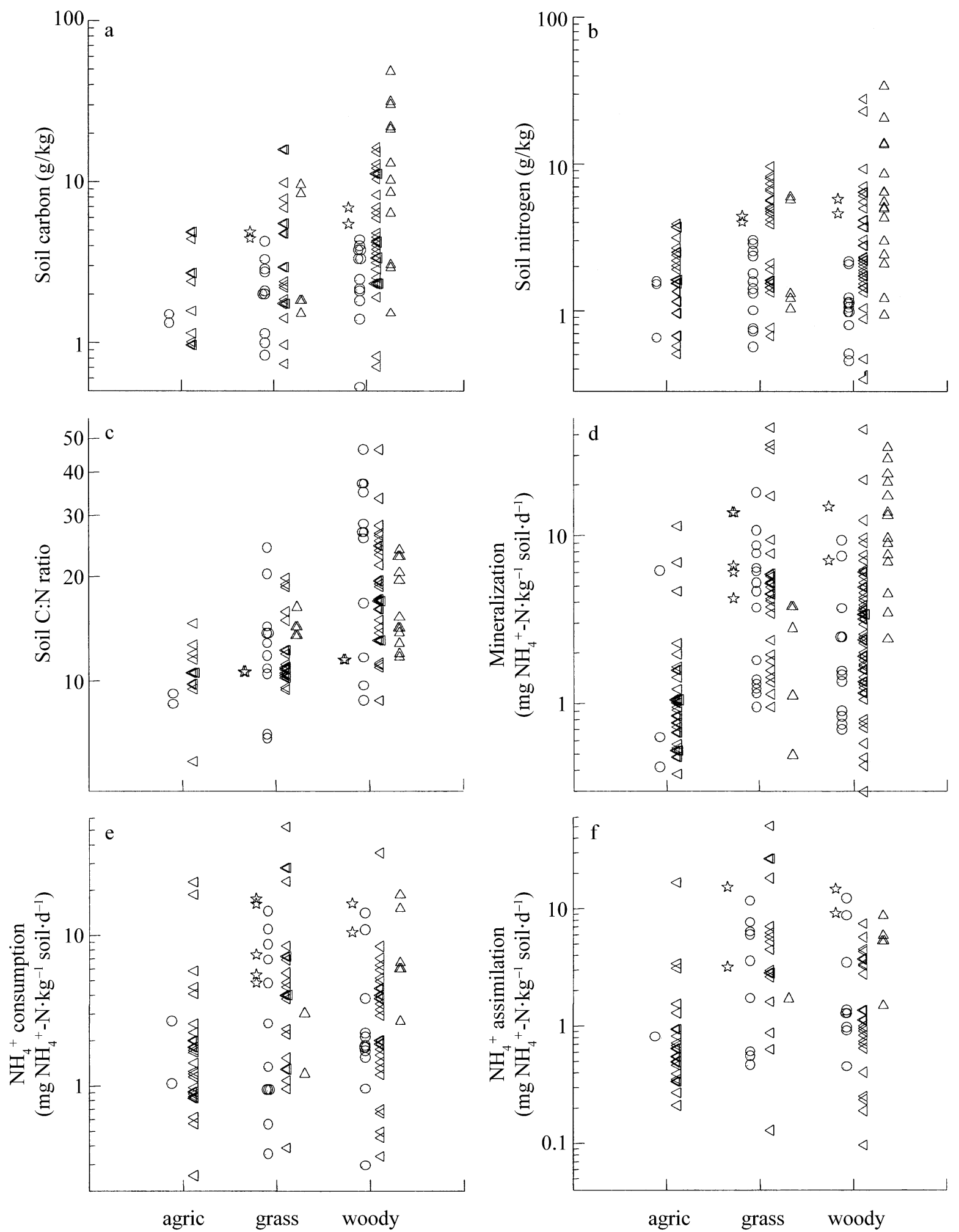

FIG. 8. Comparison of soil characteristics and gross rates in mineral soils of agricultural, grassland, and woodland ecosystems. Data from tropical forest soils were included to illustrate the range of values for forest soils of different climates but were not used in statistical comparisons among vegetation types. 

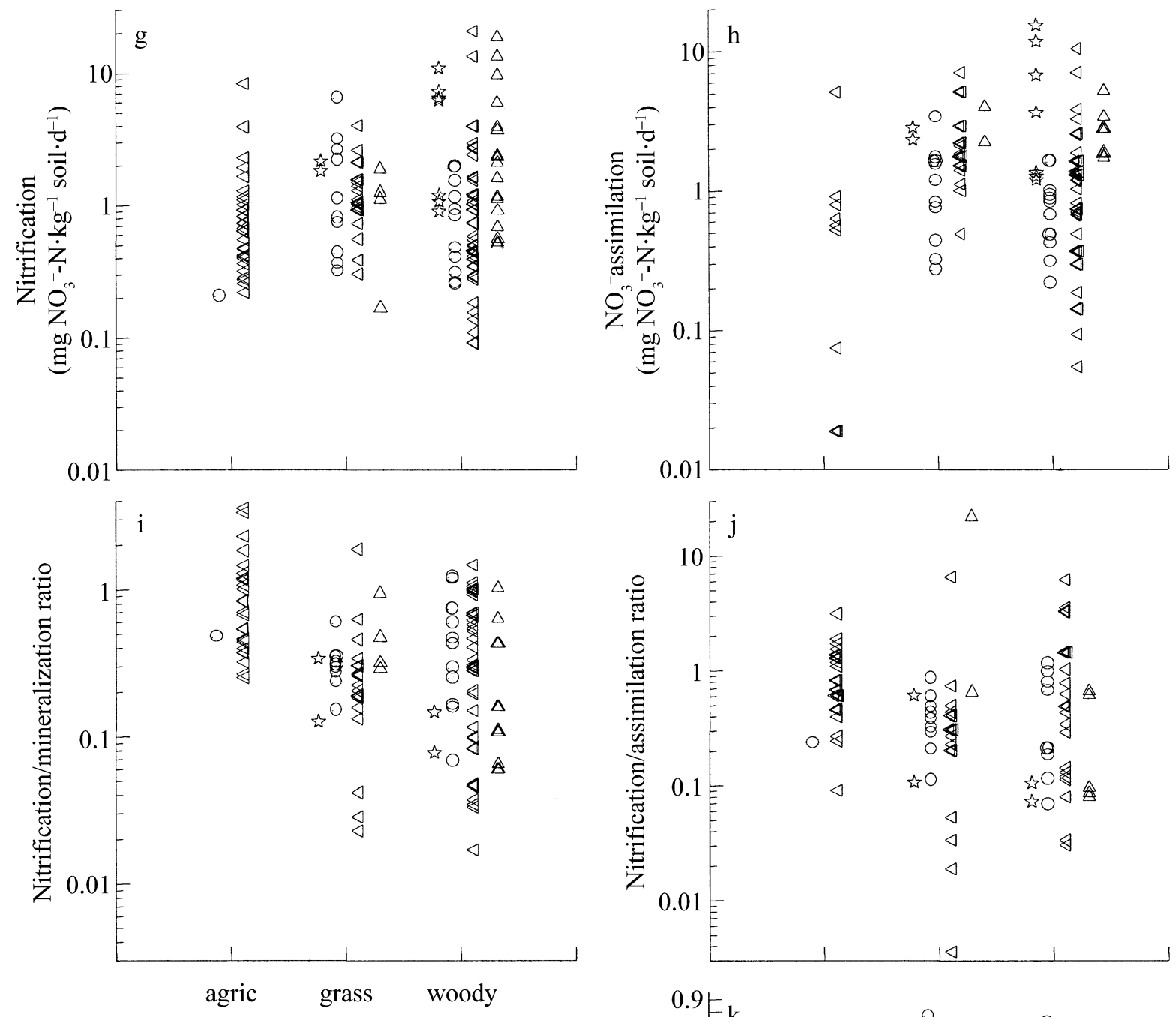

s arctic/montane
$\circ$ semiarid
$\triangleleft$ temperate
$\triangle$ tropical
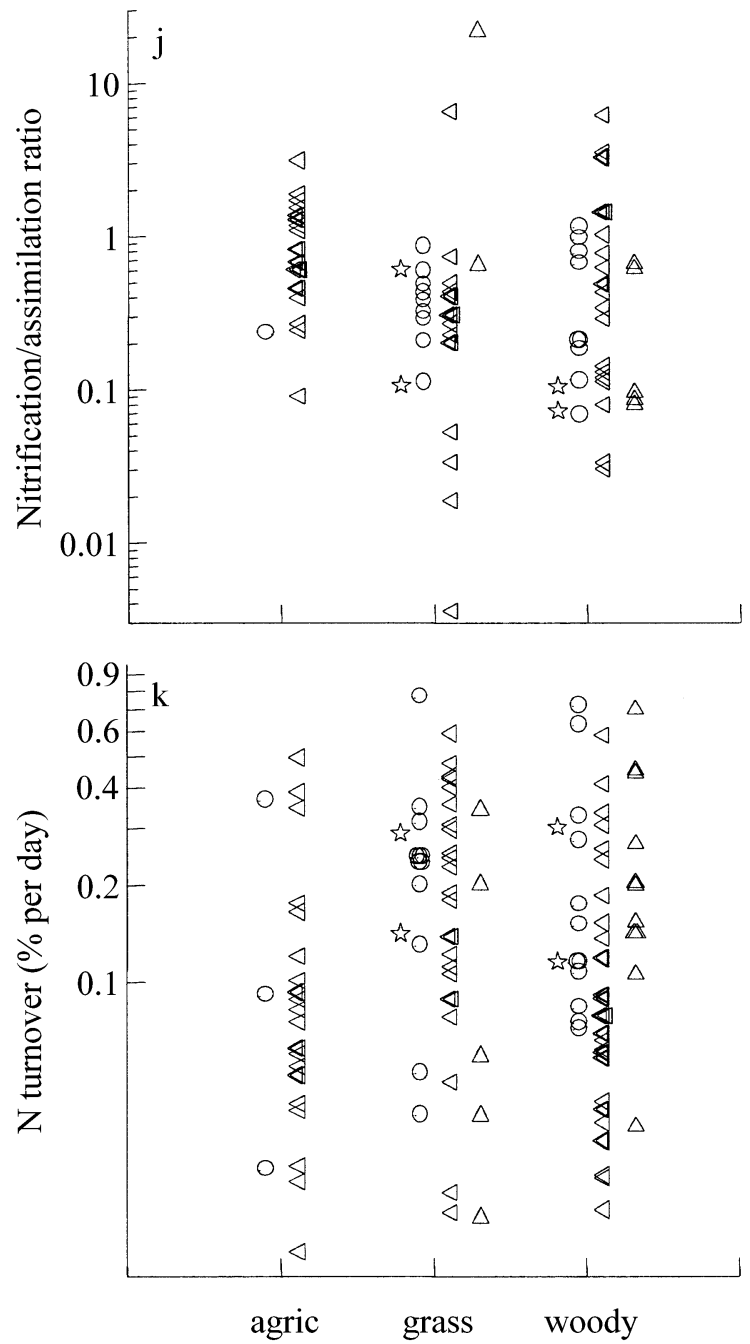

FIG. 8. Continued 
lands and woodlands or between woodlands and agricultural systems (Fig. 8e). This was one case in which a preponderance of sieved soils in the agricultural group may have biased results. Sieving stimulates $\mathrm{NH}_{4}{ }^{+}$ assimilation in some soils (Stark 1991), and thus rates in less-disturbed agricultural soil may be lower than shown in this analysis. Ammonium assimilation was highest in grasslands, intermediate in woodlands, and lowest in agricultural systems (1.64, 7.41, and 2.99 $\mathrm{mg} \mathrm{N} \cdot \mathrm{kg}^{-1}$ soil $\cdot \mathrm{d}^{-1} ; P=0.0001$; Fig. 8f). Nitrification did not differ significantly among the vegetation types (1.37, 1.82, and $2.08 \mathrm{mg} \mathrm{N} \cdot \mathrm{g}^{-1} \mathrm{soil}^{-\mathrm{d}^{-1}} ; P=0.14$; Fig. $8 \mathrm{~g}$ ). Nitrate assimilation did not differ between woodlands and grasslands, but was significantly lower in agricultural systems (1.02, 2.18, and 2.09 $\mathrm{g} \mathrm{N} \cdot \mathrm{g}^{-1}$ soil $\cdot \mathrm{d}^{-1} ; P=0.001$; Fig. $8 \mathrm{~h}$ ). Soil from agricultural systems had significantly higher mean nitrification:mineralization ratios $(1.13,0.38$, and $0.49 ; P<$ 0.0001; Fig. 8i) and nitrification : $\mathrm{NH}_{4}{ }^{+}$assimilation ratios $(1.86,0.61$, and $0.98 ; P=0.001$; Fig. $8 \mathrm{j})$, while neither of these indices differed between woodlands and grasslands. Nitrogen turnover was fastest in grasslands, but did not differ significantly between woodlands and agricultural systems $(0.13 \%, 0.21 \%$, and $0.15 \% / \mathrm{d} ; P=0.009$, Fig. $8 \mathrm{k}$ ).

We used analysis of covariance to test whether relationships between soil properties and rates differed between vegetation types. Analyses were confined to grassland and woodland soils. A significant vegetation type effect $(P=0.0005)$ in the ANCOVA of $\mathrm{N}$ mineralization on soil $\mathrm{C}$ suggests that grassland SOM is inherently more mineralizable than SOM of woodlands (Fig. 9a), perhaps due to the generally lower C:N ratio of grassland soils than woodland soils (Fig. 9b). The lack of a significant vegetation type effect in the ANCOVA of mineralization on soil $\mathrm{N}$ (Fig. 9c) reinforces the idea that higher mineralization rates at a given $\mathrm{C}$ content in grassland soils are due to greater N "yield" per unit SOM mineralized, rather than greater inherent lability of the material, although the significantly higher $\mathrm{N}$ turnover rate in grasslands than woodlands (Fig. $8 \mathrm{k}$ ) suggests that higher mineralization in grassland soils may also relate to the inherent lability of the organic $\mathrm{N}$ pool. There was no significant effect of vegetation type in the ANCOVA of $\mathrm{NH}_{4}{ }^{+}$assimilation on soil $\mathrm{C}$ or in the ANCOVA of nitrification or $\mathrm{NO}_{3}{ }^{-}$assimilation on $\mathrm{N}$ mineralization.

\section{Coniferous/deciduous comparison in woodlands}

We compared soil properties and $\mathrm{N}$ process rates in coniferous and deciduous woodlands using data from both organic and mineral soil material. We excluded data from tropical climates, however, since there were no data from coniferous ecosystems in the tropics. Reported means are for untransformed data and occur in the order coniferous, deciduous. Soil $\mathrm{C}$ concentrations (221.3 and $112.8 \mathrm{~g} \mathrm{C} / \mathrm{kg}$ soil) and $\mathrm{N}$ concentrations (8.1 and $7.0 \mathrm{~g} \mathrm{C} / \mathrm{kg}$ soil) did not differ between the
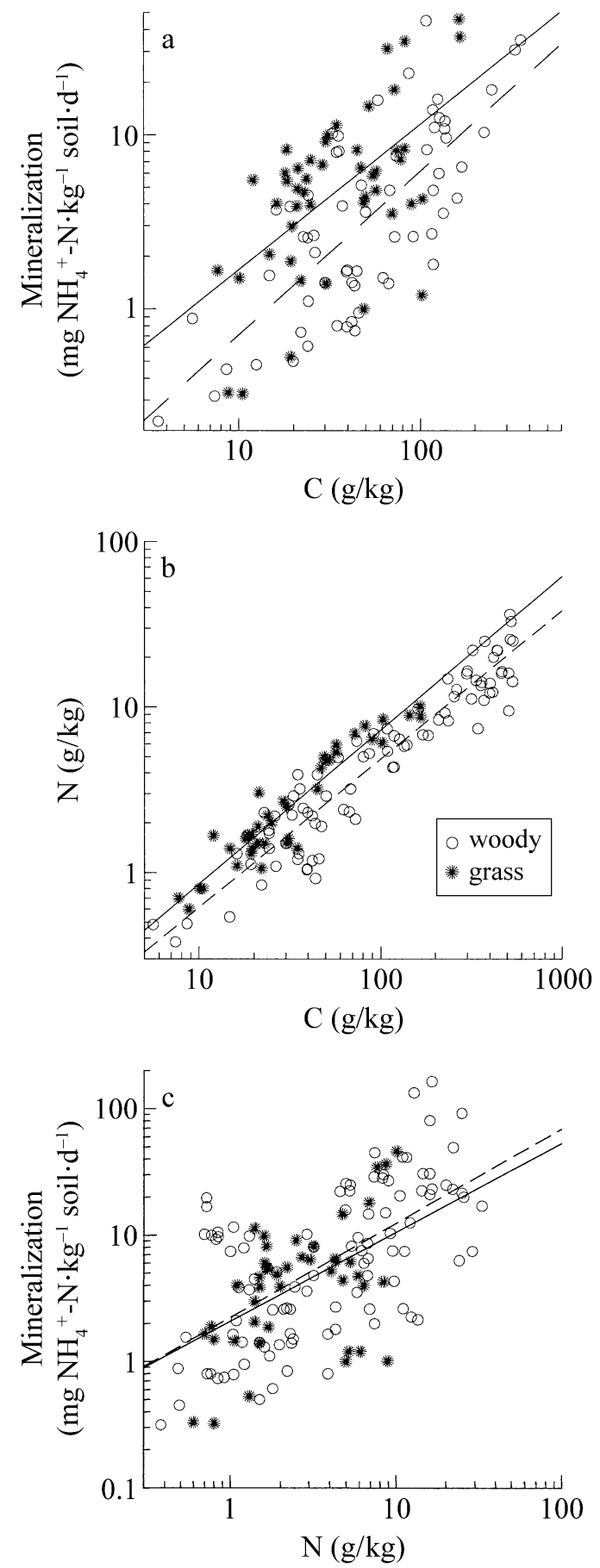

FIG. 9. The relationships between (a) mineralization and soil C, (b) $\mathrm{N}$ and soil $\mathrm{C}$, and (c) mineralization and soil $\mathrm{N}$ for mineral soil from grassland and woodland ecosystems.

two vegetation types, but soil $\mathrm{C}: \mathrm{N}$ ratio was higher in coniferous soils (27.9 and 17.97; $P=0.0001)$. While mean $\mathrm{N}$ mineralization rates did not differ between coniferous and deciduous soils (16.42 and 15.39 $\mathrm{mg} \mathrm{N} \cdot \mathrm{kg}^{-1}$ soil $\left.\cdot \mathrm{d}^{-1} ; P=0.82\right)$, there was a significant effect of vegetation type in the ANCOVA of miner- 
alization on soil $\mathrm{C}$, so that mineralization rates were higher in deciduous than coniferous soils at similar $\mathrm{C}$ concentrations $(P=0.05)$. Mean nitrification rates did not differ between the two groups (4.57 and 2.41 $\mathrm{mg} \mathrm{N} \cdot \mathrm{kg}^{-1}$ soil $\left.\cdot \mathrm{d}^{-1} ; P=0.72\right)$, nor did their relationship to mineralization as measured by ANCOVA.

\section{Climate comparisons in woodlands}

We confined our comparison of climatic regimes to data from mineral and organic soil from deciduous woodlands of tropical, temperate, and semiarid climates. Carbon concentrations were similar in soil material from the three groups, while $\mathrm{N}$ concentrations were lowest in soil from semiarid woodlands $(P=$ $0.005)$. Soil $\mathrm{C}: \mathrm{N}$ ratio was lower in tropical soils than semiarid soils, but did not differ between tropical and temperate soils $(P=0.03)$. Analysis of covariance indicated that there were no differences among the climate groups in the relationships between soil $\mathrm{C}$ concentration and either $\mathrm{N}$ mineralization or $\mathrm{NH}_{4}{ }^{+}$assimilation and between nitrification and $\mathrm{N}$ mineralization.

\section{DisCUSSION}

Based on our review, we can provide at least preliminary answers to the general questions posed in the introduction: What are the major controls on mineralization, nitrification, and uptake of mineral N? And, are there differences in rates or relationships among rates and soil characteristics in different types of ecosystems? Despite the heterogeneity of the data set, there were clear relationships between gross $\mathrm{N}$ process rates and soil properties over a wide range of ecosystems. The main findings from our analysis of the literature were:

1) Both microbial biomass $\mathrm{N}$ and mineralization are positively related to soil $\mathrm{C}$ and $\mathrm{N}$ concentration, while $\mathrm{C}: \mathrm{N}$ ratio exerts a secondary, negative influence.

2) A suite of factors covaries with $\mathrm{N}$ mineralization, including $\mathrm{NH}_{4}^{+}$consumption, $\mathrm{NH}_{4}^{+}$assimilation, extractable $\mathrm{NH}_{4}^{+}$, and nitrification. Nitrate assimilation and extractable $\mathrm{NO}_{3}{ }^{-}$covary with nitrification (and thus with mineralization, as well).

3) Nitrification is strongly related to $\mathrm{N}$ mineralization but is proportionally most important as a fate of $\mathrm{NH}_{4}^{+}$at low mineralization rates. There is no clear effect of $\mathrm{pH}$ on nitrification.

4) Most soil $\mathrm{NH}_{4}{ }^{+}$pools and soil $\mathrm{NO}_{3}{ }^{-}$pools have turnover times of $\sim 1 \mathrm{~d}$.

5) Grassland soils have lower $\mathrm{C}: \mathrm{N}$ ratios than woodland soils, and rates of $\mathrm{N}$ mineralization are higher in grassland soils than in woodland soils with similar soil C concentrations.

6) Deciduous woodland soils have lower $\mathrm{C}: \mathrm{N}$ ratios than coniferous woodland soils, and rates of $\mathrm{N}$ mineralization are higher in deciduous soils than in coniferous soils with similar soil $\mathrm{C}$ concentrations.

\section{Controls on mineralization, nitrification, and $N$ assimilation}

Microbial biomass $\mathrm{C}$ and $\mathrm{N}$ and soil $\mathrm{C}$ and $\mathrm{N}$ concentrations are all predictive of $\mathrm{N}$ mineralization, leading to the straightforward conclusion that inorganic $\mathrm{N}$ production increases as microbial activity and substrate concentration increase. However, the significant negative effect of soil $\mathrm{C}: \mathrm{N}$ ratio on mineralization when regressed in conjunction with soil $\mathrm{C}$ suggests that SOM composition also plays a role in regulating $\mathrm{N}$ mineralization, perhaps in part through its influence on microbial biomass. The soil $\mathrm{C}: \mathrm{N}$ ratio may represent an index of the units of $\mathrm{N}$ "liberated" per unit $\mathrm{C}$ during mineralization or serve as a proxy for covarying factors that affect recalcitrance, such as lignin content. Differences in $\mathrm{N}$ mineralization rates among ecosystem types reflect the importance of SOM composition and the activity of the microbial biomass. At a given $\mathrm{C}$ concentration, $\mathrm{N}$ mineralization rates are higher in grasslands than woodlands and higher in deciduous forests than coniferous forests. These results are consistent with relatively low soil $\mathrm{C}: \mathrm{N}$ in grasslands and deciduous forests. The higher $\mathrm{N}$ turnover rate (Fig. 8k) and higher proportion of total $\mathrm{C}$ represented by the microbial biomass in grasslands is congruent with the overall greater lability of the SOM pool in these systems and may reflect dominance by bacteria in grasslands and fungi in woodlands (although microbial biomass $\mathrm{C}: \mathrm{N}$ ratios did not differ between grasslands and woodlands in this data set).

Nitrification was strongly linked to the $\mathrm{NH}_{4}{ }^{+}$production rate and occurred over the entire range of mineralization rates in the wide variety of ecosystem types represented in the study. While mineralization appears to vary with SOM quality, the relationship of nitrification to mineralization was consistent and does not seem to vary among vegetation types, growth forms, or climates.

Studies measuring net nitrification rates have reported that nitrification declines at $\mathrm{pH}<7.0$ with a lower limit of approximately 4.5 (Haynes 1996, Myrold 1998). It is therefore surprising that our analysis showed no relationship between $\mathrm{pH}$ and nitrification, even though our analysis included soils with $\mathrm{pH}$ as low as 3.0. High $\mathrm{NH}_{4}{ }^{+}$production in soils of high organic matter content appears to be the dominant influence on nitrification, despite the decline in $\mathrm{pH}$ that often accompanies increasing SOM concentration (Fig. 3b). It is also possible that the process of heterotrophic nitrification, where organic $\mathrm{N}$ or $\mathrm{NH}_{4}{ }^{+}$is converted to $\mathrm{NO}_{2}{ }^{-}$ or $\mathrm{NO}_{3}{ }^{-}$by a diverse group of organisms, may account for an increased proportion of nitrification rates at low $\mathrm{pH}$, especially in soils containing low $\mathrm{C}: \mathrm{N}$ organic matter. Recent evidence, however, indicates that autotrophic rather than heterotrophic nitrifiers are likely the main nitrifying agents even in acid soils (DeBoer and Kowalchuck 2001). Strains of Nitrosospira sp. have been identified in some of the low $\mathrm{pH}$ soils used in our

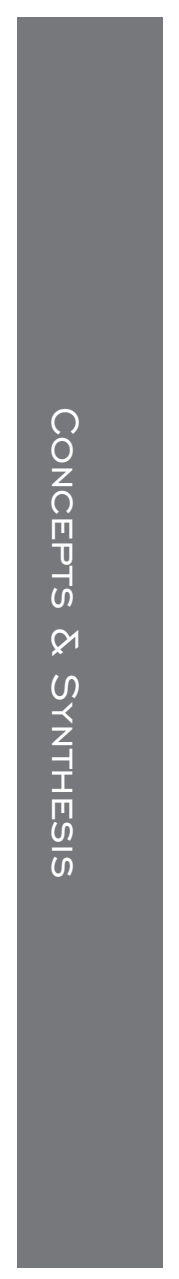


analysis (Mintie et al. 2003). These may be acid tolerant strains, or they may be acid sensitive strains that colonize microsites where $\mathrm{N}$ mineralization consumes protons and increases $\mathrm{pH}$. While heterotrophic nitrification has been reported to account for a measurable proportion of nitrification in some woodland soils (Schimel et al. 1984, Duggin et al. 1991, Barraclough and Puri 1995, Hart et al. 1997), other surveys have shown little or no heterotrophic nitrification, even at very low pH (Stark and Hart 1997). There are still too few studies that independently examine heterotrophic nitrification to evaluate its importance in explaining coarse-scale patterns in gross nitrification.

Rates of $\mathrm{NH}_{4}{ }^{+}$consumption (i.e., assimilation plus nitrification) were frequently greater than rates of $\mathrm{NH}_{4}{ }^{+}$ production. This imbalance can obviously not continue very long before $\mathrm{NH}_{4}{ }^{+}$pools become depleted, and it is often attributed to the fact that ${ }^{15} \mathrm{NH}_{4}{ }^{+}$is added during the isotope dilution assay, which can stimulate consumption rates. While isotope dilution is best used to estimate production rates, the stimulatory effect on consumption rates observed when $\mathrm{NH}_{4}{ }^{+}$is added is also of interest, since it indicates that $\mathrm{NH}_{4}{ }^{+}$availability is limited in at least some microsites. However, because both heterotrophic microorganisms and nitrifiers may be stimulated by added ${ }^{15} \mathrm{NH}_{4}^{+}$, it is not always clear which process is $\mathrm{NH}_{4}^{+}$limited. If unstimulated rates of assimilation need to be measured, inorganic $\mathrm{N}$ consumption can be estimated from mineralization - net mineralization, where net mineralization is determined in separate samples that do not receive ${ }^{15} \mathrm{~N}$ (Hart et al. 1994).

Laboratory studies report that heterotrophic microorganisms have a preference for $\mathrm{NH}_{4}{ }^{+}$over $\mathrm{NO}_{3}{ }^{-}$during assimilation and that high $\mathrm{NH}_{4}{ }^{+}$concentrations can repress $\mathrm{NO}_{3}{ }^{-}$transport or production of the $\mathrm{NO}_{3}{ }^{-}$reductase enzyme (Van't Riet et al. 1968, Sias and Ingraham 1979, Betlach et al. 1981, Rice and Tiedje 1989). However, as is the case with $\mathrm{pH}$, it appears that an effect demonstrated clearly in laboratory studies is more ambiguous in a natural situation. In the data set as a whole, $\mathrm{NO}_{3}{ }^{-}$assimilation is positively correlated with both $\mathrm{NH}_{4}{ }^{+}$concentrations and $\mathrm{N}$ mineralization rates. However, the proportion of total assimilation comprised by $\mathrm{NO}_{3}{ }^{-}$assimilation declines as mineralization increases (Fig. 5a). This decline may be a result of either progressive (but incomplete) inhibition of $\mathrm{NO}_{3}{ }^{-}$assimilation by $\mathrm{NH}_{4}{ }^{+}$or simply due to the fact that $\mathrm{NH}_{4}{ }^{+}$is more available than $\mathrm{NO}_{3}{ }^{-}$at higher $\mathrm{N}$ mineralization rates (Fig. 4). The less-defined relationship between extractable $\mathrm{NO}_{3}{ }^{-}$and $\mathrm{NO}_{3}{ }^{-}$assimilation than between extractable $\mathrm{NH}_{4}{ }^{+}$and $\mathrm{NH}_{4}{ }^{+}$assimilation (Fig. 5b) suggests that multiple factors may impinge on microbial $\mathrm{NO}_{3}{ }^{-}$assimilation, including how the isotope dilution assay was conducted. The trend toward higher $\mathrm{NO}_{3}{ }^{-}$assimilation rates in assays that used intact cores, rather than sieved soils, could indicate that $\mathrm{NO}_{3}^{-}$ assimilation primarily occurs in microsites where $\mathrm{NH}_{4}{ }^{+}$ has been depleted (Chen and Stark 2000) and that $\mathrm{NO}_{3}{ }^{-}$ assimilation is suppressed when microsite structure is disrupted by sieving and $\mathrm{NH}_{4}{ }^{+}$is more evenly distributed. Generally, however, the similar relationships of production, assimilation, and extractable inorganic $\mathrm{N}$ to soil $\mathrm{C}$ (Fig. 4a, b) suggest that for both $\mathrm{NH}_{4}{ }^{+}$and $\mathrm{NO}_{3}{ }^{-}$, rates and pools exist in a quasi-equilibrium state with SOM concentration. This approximate equivalence of daily rates and pools means that even over a wide range of soil $\mathrm{C}$ concentrations, the mean residence time for both $\mathrm{NH}_{4}^{+}$and $\mathrm{NO}_{3}{ }^{-}$is about a day.

While the analysis did not control for the effects of soil temperature and moisture on gross rates, certain patterns emerged. Mineralization has been shown to increase with rising temperature (Shaw and Harte 2001), though assimilation may increase more than mineralization (Binkley et al. 1994, Andersen and Jensen 2001). When $\mathrm{NH}_{4}{ }^{+}$is readily available, nitrification responds positively to increasing temperature for the range of temperatures typically encountered in the field (Stark 1996), but it may respond negatively to increasing temperature where $\mathrm{NH}_{4}{ }^{+}$assimilation is stimulated (Binkley et al. 1994). There were no rate differences in the climate comparison we conducted. However, it is likely that many incubations were conducted in somewhat homogenized laboratory conditions, which could minimize differences among studies.

For this data set, there was a significant positive relationship between soil moisture and $\mathrm{N}$ mineralization for transformed data (Table 3), but since soil moistureholding capacity increases with SOM concentration, it is difficult to separate the influences of $\mathrm{C}, \mathrm{N}$, and moisture content on mineralization. Individual studies report that mineralization increases with soil moisture (Pilbeam et al. 1993, Fisk et al. 1998, Willison et al. 1998 b, Jamieson et al. 1999), though under saturated conditions, mineralization continues but assimilation is inhibited (Nishio et al. 1994). Nitrification may respond positively to increasing soil moisture up to $-0.01 \mathrm{MPa}$ (Stark and Firestone 1995, Low et al. 1997) and then decline as the soil becomes saturated (Breuer et al. 2002, Corre et al. 2003). Ammonium assimilation can be more inhibited by soil drying than mineralization (Compton and Boone 2002), and $\mathrm{NO}_{3}{ }^{-}$assimilation is inhibited before nitrification in drying soils (Low et al. 1997, Compton and Boone 2002), suggesting that net rates of inorganic N production can increase as soils dry. The act of injecting ${ }^{15} \mathrm{~N}$ into soils in a liquid form may itself stimulate rates; there is some indication of lower calculated nitrification rates when ${ }^{15} \mathrm{~N}$ is added in a powder, rather than liquid form (Willison et al. 1998a, $b$ ), although lower rates may result from non-uniform distribution of ${ }^{15} \mathrm{~N}$ associated with powder additions. Some studies have found that calculated rates decline as the length of the incubation increases (Berntson and Bazzaz 1998), possibly due to soil drying (Sparling et al. 1995) or the depletion of readily available substrates (Saetre and Stark 2005). However, the appearance of diminished mineralization rates as incubation time increases could also come about 
if there is significant recycling of ${ }^{15} \mathrm{~N}$ into the product pool, as can occur if ${ }^{15} \mathrm{NH}_{4}{ }^{+}$that has been assimilated is remineralized (Wessel and Tietema 1992, Mary et al. 1998) or if ${ }^{15} \mathrm{NH}_{4}{ }^{+}$is nitrified and then reduced back to $\mathrm{NH}_{4}{ }^{+}$through dissimilatory nitrate reduction. The latter process may represent a measurable fate for $\mathrm{NO}_{3}{ }^{-}$in wetter soils (Bengtsson and Bergwall 2000, Silver et al. 2001, Müller et al. 2004).

\section{The balance of nitrification and microbial assimilation}

In contrast to expectations that nitrifiers should not persist at low $\mathrm{NH}_{4}{ }^{+}$supply rates, the nonlinear power relationship for untransformed data suggests that while nitrification is inevitably reduced when $\mathrm{NH}_{4}{ }^{+}$supply is limited, it is a proportionally more important fate for $\mathrm{NH}_{4}{ }^{+}$at lower rather than higher rates of $\mathrm{N}$ mineralization. The diminishing proportion of $\mathrm{NH}_{4}{ }^{+}$nitrified at higher mineralization rates (Fig. 6) suggests that nitrifier population size may be limited by the increasingly unfavorable energetics of nitrification at higher values on the soil $\mathrm{C} /$ mineralization gradient. While heterotrophs only require $\mathrm{N}$ to construct new biomass, autotrophic nitrifiers require $\mathrm{N}$ for both energy production and biomass construction. Moving up the soil $\mathrm{C} /$ mineralization gradient, higher $\mathrm{C}$ soils should support greater populations of heterotrophs, which assimilate $\mathrm{NH}_{4}{ }^{+}$to the detriment of nitrifiers. Nitrification may be confined to Cdepleted microsites (Chen and Stark 2000), which may constitute a diminishing proportion of the soil as soil $\mathrm{C}$ concentration increases.

Soil organic matter quality, as well as quantity, may also determine the balance of heterotrophic and nitrifier uptake of mineralized N. Light fraction SOM, which tends to be young, mostly plant-derived, and have a higher C:N ratio than heavy fraction SOM (Hassink et al. 1997, Trumbore 1997, Sollins et al. 1999), can be lost when soils are disturbed (Alvarez et al. 1998, Wang et al. 1999) or experience a shift in vegetation (Compton and Boone 2000, Jackson et al. 2001, Roscoe et al. 2001). Loss of the light fraction appears to be particularly important for microbial $\mathrm{N}$ immobilization (Whalen et al. 2000, Compton and Boone 2002, Neff et al. 2002). Elevated nitrification rates following trenching in a New Zealand pine plantation suggest that the cessation of labile $\mathrm{C}$ inputs by roots diminishes heterotrophic $\mathrm{NH}_{4}{ }^{+}$ assimilation, shifting the competitive balance in favor of nitrifiers (Ross et al. 2001). Augmented plant C inputs to soils under elevated $\mathrm{CO}_{2}$ may also affect the fate of $\mathrm{NH}_{4}{ }^{+}$by increasing heterotrophic $\mathrm{NH}_{4}{ }^{+}$uptake (Hungate et al. 1997b, 1999, Mikan et al. 2000) and decreasing nitrification rates (Hungate et al. 1997b, 1999), although this trend is not consistent across sites.

Changes in inorganic $\mathrm{N}$ dynamics with soil $\mathrm{C}$ depletion may have special significance for soils where $\mathrm{N}$ and $\mathrm{C}$ availability are uncoupled, as in systems receiving high atmospheric $\mathrm{N}$ deposition or agricultural soils where $\mathrm{C}$ may be depleted and $\mathrm{N}$ amended. Organic $\mathrm{C}$ depletion resulting from tillage can still be detected over $100 \mathrm{yr}$ after land abandonment (Compton and Boone 2000), suggesting that changes in inorganic N cycling may also be long-lasting. In a study of agricultural soils, Stockdale et al. (2002) found that the nitrification : assimilation ratio covaried with independently assessed measures of nitrate leaching, and Goulding et al. (1998) suggested that the nitrification: assimilation ratio may provide an index of ecosystem $\mathrm{N}$ saturation. In our review, both ratios were higher in agricultural soils than in grassland or woodland soils, an effect that may be due in part to historic fertilization of agricultural soils. However, the relatively greater importance of nitrification as a fate for $\mathrm{NH}_{4}{ }^{+}$at lower mineralization rates was consistent even when agricultural soils were excluded from the analysis, suggesting that it is indeed SOM concentration that determines the relative proportion of $\mathrm{NH}_{4}{ }^{+}$that is nitrified, rather than a history of fertilization. In any case, "fertilization" due to anthropogenic $\mathrm{N}$ deposition is increasing in ecosystems worldwide (Galloway and Cowling 2002), which itself may accelerate C loss from soils (Neff et al. 2002). Soils thus impacted may increasingly shift to a more nitrate-based inorganic $\mathrm{N}$ economy, as is observed with agricultural soils.

\section{Effect of elevated atmospheric $\mathrm{CO}_{2}$ on gross rates}

Because there were several studies that examined gross rates in soils of plant communities exposed to elevated $\mathrm{CO}_{2}$ (Hungate et al. 1997a, b, 1999, Berntson and Bazzaz 1998, Mikan et al. 2000, Williams et al. 2001, Richter et al. 2003), we compiled the data from these studies to reanalyze it using paired $t$ tests, with $\mathrm{CO}_{2}$ level as the grouping variable. However, conclusions about the effect of elevated $\mathrm{CO}_{2}$ on gross rates varied among studies, and we found no differences between the control and enhanced $\mathrm{CO}_{2}$ treatments in absolute rates or ratios of rates (nitrification : $\mathrm{NH}_{4}{ }^{+}$assimilation and nitrification : mineralization). To summarize the conclusions of various studies: Hungate et al. (1997a) concluded that apparent stimulation of $\mathrm{N}$ mineralization in an annual grassland system under elevated $\mathrm{CO}_{2}$ was actually due to increased soil moisture retention that resulted from decreased plant transpiration. However, elevated $\mathrm{CO}_{2}$ was found to stimulate microbial $\mathrm{NH}_{4}{ }^{+}$assimilation, in turn reducing nitrification rates in a nutrient-addition treatment, relative to the fertilized, ambient $\mathrm{CO}_{2}$ control (Hungate et al. 1997b). In a Florida oak woodland, Hungate et al. (1999) saw decreased N mineralization and nitrification but elevated microbial assimilation under increased $\mathrm{CO}_{2}$. Berntson and Bazzaz (1998) found reduced $\mathrm{N}$ mineralization and consumption rates in temperate forest microcosms under elevated $\mathrm{CO}_{2}$. Mikan et al. (2000) determined no effect of $\mathrm{CO}_{2}$ on $\mathrm{N}$ mineralization in constructed aspen microcosms, but did see increased $\mathrm{NH}_{4}{ }^{+}$consumption that was unaccompanied by any increase in microbial biomass. Richter et al. (2003) did not see any effect of elevated

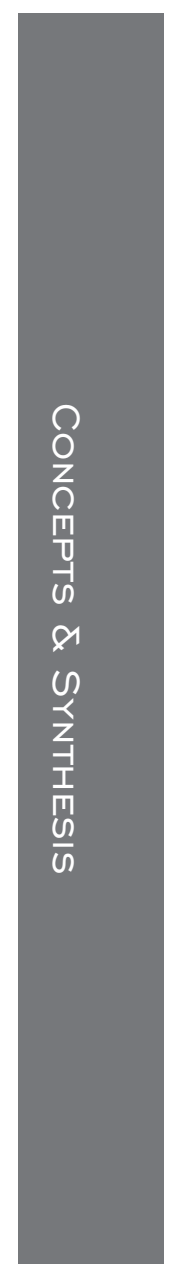


$\mathrm{CO}_{2}$ on $\mathrm{N}$ mineralization or consumption in a fertilized perennial grassland, even after $7 \mathrm{yr}$ of increased $\mathrm{CO}_{2}$. However, they did not assay nitrification, thus the lack of a $\mathrm{CO}_{2}$ effect on consumption rates could have been due to the counterbalancing of increased microbial $\mathrm{NH}_{4}{ }^{+}$ assimilation and decreased nitrification, as was observed by Hungate et al. (1997b).

\section{Fertilization effects on gross rates}

Surprisingly, our analysis of the group of studies with a fertilization treatment showed no effect of fertilization on any variable, although individual studies did detect significant increases in mineralization, nitrification, or both with fertilization (Hungate et al. 1997b, Ledgard et al. 1998, Hall and Matson 1999, Zaman et al. 1999, Bradley et al. 2000a, Hatch et al. 2000a, 2002, Fisk and Fahey 2001, Nishio et al. 2001, Stockdale et al. 2002). There is evidence to suggest that the nature of the amendment makes a difference. Nitrogen additions stimulate mineralization when they are accompanied by organic matter, such as occurs with manure or compost additions (Zaman et al. 1999, Burger and Jackson 2003; Shi et al. 2004) or in cases where long-term $\mathrm{N}$ additions have been incorporated in organic matter (Hall and Matson 1999, 2003, Bradley et al. 2000b, Hatch et al. $2000 b$ ). However, additions of mineral $\mathrm{N}$ alone will not necessarily stimulate and may even depress mineralization (Unkovich et al. 1998, Fisk and Fahey 2001, Corre et al. 2003) and SOM decomposition rates (Berg 2000, Allison and Vitousek 2001). As expected, nitrification is often stimulated by $\mathrm{N}$ additions (Hall and Matson 1999, Zaman et al. 1999, Fisk and Fahey 2001, Stockdale et al. 2002, Hall and Matson 2003).

\section{Contrasting net and gross rate assays}

Although net rates are often reported as a measure of production of inorganic $\mathrm{N}$, they represent the difference between production and consumption processes, and thus there is little reason to anticipate that they should vary in a consistent way with SOM concentration. This is in contrast to gross mineralization rates and extractable inorganic $\mathrm{N}$ pools, which track each other closely and appear to exist somewhat in equilibrium with SOM concentration (Fig. 4). Unfortunately, for the few studies that assayed both net and gross mineralization, vegetation type was confounded with the length of the net mineralization assay, which precluded proper statistical analysis. Nevertheless, the steeper relationship between net and gross rates for $7-\mathrm{d}$ incubations than $30-\mathrm{d}$ incubations suggests that once a certain amount of $\mathrm{N}$ has been mineralized further increases in inorganic $\mathrm{N}$ pools may be inhibited, and thus, the calculated net rate may decline with longer incubation.

Depending on the question of interest, however, either gross or net rates assays may provide more appropriate insights. Ideally, gross rates should provide more mechanistic information than net rates, such as the effect of soil characteristics on inorganic $\mathrm{N}$ production and con- sumption or relationships between rates, as reported here. For instance, ascertaining true rates of nitrification (and consequent denitrification) would seem to be a prerequisite for predicting rates of trace $\mathrm{N}$ gas production, one important intersection of $\mathrm{N}$ cycling with global climate change. However, efforts to correlate trace gas flux with gross rates of nitrification have met with only mixed success (Davidson et al. 1993, Riley and Vitousek 1995, Breuer et al. 2002), and net nitrification may be a stronger predictor for trace gas emission than gross nitrification (Stark et al. 2002). As an assay for "plant-available" inorganic $\mathrm{N}$, the reality of what is available to plants must lie somewhere between net rates and gross rates. For both kinds of assays, it is likely that microbes take up more $\mathrm{N}$ than they would in the presence of competition by roots (Schmidt et al. 2002). The problem is further compounded because $\mathrm{N}$ mineralization (both gross and net) is typically assayed in bulk soils, but experimental evidence suggests that $\mathrm{N}$ cycling rates are higher in rhizosphere soils than bulk soil (Norton and Firestone 1996), probably due to locally higher C availability and microbial biomass (Zak et al. 1993, Priha et al. 1999) and, possibly, a faster turnover of microbial $\mathrm{N}$ due to grazing by mesofauna (Clarholm 1985, Alphei et al. 1996, Myrold 1998). Greater active microbial biomass in rhizosphere soils than bulk soils may lead to higher rates of both $\mathrm{N}$ mineralization and microbial assimilation, but spatial or temporal segregation of these two processes may allow roots to acquire mineralized $\mathrm{N}$ as it "goes by" that might otherwise be taken up by microbes if the roots were not present.

\section{Conclusions}

Results of this synthesis highlight the importance of both substrate quantity (as $\mathrm{C}$ and $\mathrm{N}$ concentration) and quality (as $\mathrm{C}: \mathrm{N}$ ratio) for $\mathrm{N}$ cycling rates and the relative importance of nitrification in the inorganic $\mathrm{N}$ economy. Both substrate availability and soil $\mathrm{C}: \mathrm{N}$ ratio influence $\mathrm{N}$ mineralization rates, effects that translate into characteristic differences in $\mathrm{N}$ cycling among ecosystem types, even given the wide variety of studies included in this review. Nitrification appears to be controlled primarily by the $\mathrm{NH}_{4}{ }^{+}$supplied by mineralization, but secondarily by competing fates for $\mathrm{NH}_{4}{ }^{+}$, which reduce substrate availability. Soil C availability, as it promotes microbial $\mathrm{N}$ assimilation, plays a central role in regulating net nitrification at both "ends" of the process: heterotrophic assimilation of $\mathrm{NH}_{4}^{+}$reduces gross nitrification, and assimilation of $\mathrm{NO}_{3}{ }^{-}$reduces $\mathrm{NO}_{3}{ }^{-}$accumulation in soils. When soil $\mathrm{C}$ is lost due to agricultural practices, changes in vegetation, or climatic factors, nitrifiers may become increasingly able to compete against heterotrophic microorganisms for $\mathrm{NH}_{4}{ }^{+}$.

\section{ACKNOWLEDGMENTS}

This research was supported by a grant from The Andrew W. Mellon Foundation to The Ecosystems Center of the Marine Biological Laboratory, Woods Hole, Massachusetts, and by a grant from the National Science Foundation to Utah State University, Logan, Utah. 


\section{Literature Cited}

Aber, J. D. 1992. Nitrogen cycling and nitrogen saturation in temperate forest ecosystems. Trends in Ecology and Evolution 7:220-224.

Allison, S., and P. M. Vitousek. 2004. Extracellular enzyme activities and carbon chemistry as drivers of tropical plant litter decomposition. Biotropica 36:285-296.

Alphei, J., M. Bonkowski, and S. Scheu. 1996. Protozoa, Nematoda and Lumbricidae in the rhizosphere of Hordelymus europaeus (Poaceae): faunal interactions, response of microorganisms and effects on plant growth. Oecologia 106:111-126.

Alvarez, C. R., R. Alvarez, M. S. Grigera, and R. S. Lavado. 1998. Associations between organic matter fractions and the active soil microbial biomass. Soil Biology and Biochemistry 30:767-773.

Andersen, M. K., and L. S. Jensen. 2001. Low soil temperature effects on short-term gross $\mathrm{N}$ mineralisation-immobilisation turnover after incorporation of a green manure. Soil Biology and Biochemistry 33:511-521.

Anderson, T.-H., and K. H. Domsch. 1989. Ratios of microbial biomass carbon to total organic carbon in arable soils. Soil Biology and Biochemistry 21:471-479.

Barraclough, D., and G. Puri. 1995. The use of ${ }^{15} \mathrm{~N}$ pool dilution and enrichment to separate the heterotrophic and autotrophic pathways of nitrification. Soil Biology and Biochemistry 27:17-22.

Barrett, J. E., and I. C. Burke. 2000. Potential nitrogen immobilization in grassland soils across a soil organic matter gradient. Soil Biology and Biochemistry 32:1707-1716.

Bengtsson, G., P. Bengtson, and K. F. Månsson. 2003. Gross nitrogen mineralization-, immobilization-, and nitrification rates as a function of soil $\mathrm{C} / \mathrm{N}$ ratio and microbial activity. Soil Biology and Biochemistry 35:143-154.

Bengtsson, G., and C. Bergwall. 2000. Fate of ${ }^{15} \mathrm{~N}$ labelled nitrate and ammonium in a fertilized forest soil. Soil Biology and Biochemistry 32:545-557.

Berg, B. 2000. Litter decomposition and organic matter turnover in northern forest soils. Forest Ecology and Management 133: 13-22.

Berntson, G. M., and F. A. Bazzaz. 1998. Regenerating temperate forest mesocosms in elevated $\mathrm{CO}_{2}$ : belowground growth and nitrogen cycling. Oecologia 113:115-125.

Betlach, M. R., J. M. Tiedje, and R. B. Firestone. 1981. Assimilatory nitrate uptake in Pseudomonas fluorescens studied using nitrogen-13. Archives of Microbiology 129:135140.

Binkley, D., R. Stottlemyer, F. Suarez, and J. Cortina. 1994. Soil nitrogen availability in some arctic ecosystems in northwest Alaska: responses to temperature and moisture. Ecoscience 1:64-70.

Bradley, R. L., B. D. Titus, and C. P. Preston. 2000a. Changes to mineral $\mathrm{N}$ cycling and microbial communities in black spruce humus after additions of $\left(\mathrm{NH}_{4}\right)_{2} \mathrm{SO}_{4}$ and condensed tannins extracted from Kalmia angustifolia and balsam fir. Soil Biology and Biochemistry 32:1227-1240.

Bradley, R. L., B. D. Titus, C. M. Preston, and J. Bennett. $2000 \mathrm{~b}$. Improvement of nutritional site quality 13 years after single application of fertiliser $\mathrm{N}$ and $\mathrm{P}$ on regenerating cedar-hemlock cutovers on northern Vancouver Island, BC. Plant and Soil 223:195-206.

Breuer, L., R. Kiese, and K. Butterbach-Bahl. 2002. Temperature and moisture effects on nitrification rates in tropical rain-forest soils. Soil Science Society of America Journal 66:834-844.

Burger, M., and L. E. Jackson. 2003. Microbial immobilization of ammonium and nitrate in relation to ammonification and nitrification rates in organic and conventional cropping systems. Soil Biology and Biochemistry 35:2936.
Chen, J., and J. M. Stark. 2000. Plant species effects and carbon and nitrogen cycling in a sagebrush-crested wheatgrass soil. Soil Biology and Biochemistry 32:47-57.

Clarholm, M. 1985. Possible roles for roots, bacteria, protozoa and fungi in supplying nitrogen to plants. Pages 355365 in A. H. Fitter, D. Atkinson, R. J. Read, and M. B. Usher, editors. Ecological interactions in soil. Blackwell Scientific, Oxford, UK.

Compton, J. E., and R. D. Boone. 2000. Long-term impacts of agriculture on soil carbon and nitrogen in New England forests. Ecology 81:2314-2330.

Compton, J. E., and R. D. Boone. 2002. Soil nitrogen transformations and the role of light fraction organic matter in forest soils. Soil Biology and Biochemistry 34:933-943.

Corre, M. D., F. O. Beese, and R. Brumme. 2003. Soil nitrogen cycle in high nitrogen deposition forest: changes under nitrogen saturation and liming. Ecological Applications 13:287-298.

Davidson, E. A., S. C. Hart, C. A. Shanks, and M. K. Firestone. 1991. Measuring gross nitrogen mineralization, immobilization, and nitrification by ${ }^{15} \mathrm{~N}$ isotopic pool dilution in intact soil cores. Journal of Soil Science 42:335-349.

Davidson, E. A., P. A. Matson, P. M. Vitousek, R. Riley, K. Dunkin, G. García-Méndez, and J. M. Maass. 1993. Processes regulating soil emissions of $\mathrm{NO}$ and $\mathrm{N}_{2} \mathrm{O}$ in a seasonally dry tropical forest. Ecology 74:130-139.

DeBoer, W., and G. A. Kowalchuk. 2001. Nitrification in acid soils: micro-organisms and mechanisms. Soil Biology and Biochemistry 33:853-866.

Dise, N. B., E. Matzner, and M. Forsius. 1998. Evaluation of organic horizon $\mathrm{C}: \mathrm{N}$ ratio as an indicator of nitrate leaching in conifer forests across Europe. Environmental Pollution 102:453-456.

Duggin, J. A., G. K. Voigt, and F. H. Bormann. 1991. Autotrophic and heterotrophic nitrification in response to clear-cutting northern hardwood forest. Soil Biology and Biochemistry 23:779-787.

Fisk, M. C., and T. J. Fahey. 2001. Microbial biomass and nitrogen cycling responses to fertilization and litter removal in young northern hardwood forests. Biogeochemistry 53: 201-223.

Fisk, M. C., S. K. Schmidt, and T. R. Seastedt. 1998. Topographic patterns of above- and belowground production and nitrogen cycling. Ecology 79:2253-2266.

Galloway, J., and E. Cowling. 2002. Reactive nitrogen and the world: 200 years of change. Ambio 31:64-71.

Goulding, K. W. T., N. J. Bailey, N. J. Bradbury, P. Hargreaves, M. Howe, D. V. Murphy, P. R. Poulton, and T. W. Willison. 1998. Nitrogen deposition and its contribution to nitrogen cycling and associated soil processes. New Phytologist 139:49-58.

Gundersen, P., I. Callesen, and W. de Vries. 1998. Nitrate leaching in forest ecosystems is related to forest floor $\mathrm{C} /$ $\mathrm{N}$ ratios. Environmental Pollution 102:403-407.

Hall, S. J., and P. Matson. 1999. Nitrogen oxide emissions after nitrogen additions in tropical forests. Nature 400: $152-$ 155.

Hall, S. J., and P. A. Matson. 2003. Nutrient status of tropical rain forests influences soil $\mathrm{N}$ dynamics after $\mathrm{N}$ additions. Ecological Monographs 73:107-129.

Hart, S. C., D. Binkley, and D. A. Perry. 1997. Influence of red alder on soil nitrogen transformations in two conifer forests of contrasting productivity. Soil Biology and Biochemistry 29:1111-1123.

Hart, S., G. E. Nason, D. D. Myrold, and D. A. Perry. 1994. Dynamics of gross nitrogen transformations in an oldgrowth forest: the carbon connection. Ecology 75:880-891.

Hassink, J., A. P. Whitmore, and J. Kubát. 1997. Size and density fractionation of soil organic matter and the physical

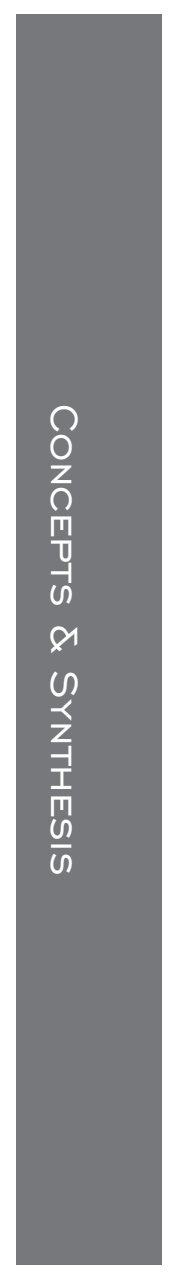


capacity of soils to protect organic matter. European Journal of Agronomy 7:189-199.

Hatch, D. J., S. C. Jarvis, R. J. Parkinson, and R. D. Lovell. $2000 a$. Combining field incubation with nitrogen-15 labelling to examine nitrogen transformations in low to high intensity grassland management systems. Biology and Fertility of Soils 30:492-499.

Hatch, D. J., R. D. Lovell, R. S. Antil, S. C. Jarvis, and P. M. Owen. 2000b. Nitrogen mineralization and microbial activity in permanent pastures amended with nitrogen fertilizer or dung. Biology and Fertility of Soils 30:288-293. [Erratum: 2000. 31:360.]

Hatch, D. J., M. S. Sprosen, S. C. Jarvis, and S. F. Ledgard. 2002. Use of labelled nitrogen to measure gross and net rates of mineralization and microbial activity in permanent pastures following fertilizer applications at different time intervals. Rapid Communications in Mass Spectrometry 16:2172-2178.

Haynes, R. J. 1996. Nitrification. Pages 127-165 in R. J. Haynes, editor. Mineral nitrogen in the plant-soil system. Academic Press, New York, New York, USA.

Hirobe, M., K. Koba, and N. Tokuchi. 2003. Dynamics of the internal soil nitrogen cycles under moder and mull forest floor types on a slope in a Cryptomeria japonica D. Don plantation. Ecological Research 18:53-64.

Hungate, B. A., F. S. Chapin, H. Zhong, E. A. Holland, and C. B. Field. 1997a. Stimulation of grassland nitrogen cycling under carbon dioxide enrichment. Oecologia 109: 149-153.

Hungate, B. A., P. Dijkstra, D. W. Johnson, C. R. Hinkle, and B. G. Drake. 1999. Elevated $\mathrm{CO}_{2}$ increases nitrogen fixation and decreases soil nitrogen mineralization in Florida scrub oak. Global Change Biology 5:781-789.

Hungate, B. A., C. P. Lund, H. L. Pearson, and F. S. Chapin. 1997b. Elevated $\mathrm{CO}_{2}$ and nutrient addition alter soil $\mathrm{N}$ cycling and $\mathrm{N}$ trace gas fluxes with early season wet-up in a California annual grassland. Biogeochemistry 37:89109.

Jackson, R. B., J. L. Banner, E. G. Jobbágy, W. T. Pockman, and D. H. Wall. 2001. Ecosystem carbon loss with woody plant invasion of grasslands. Nature 418:623-626.

Jamieson, N., R. Monaghan, and D. Barraclough. 1999. Seasonal trends of gross $\mathrm{N}$ mineralization in a natural calcareous grassland. Global Change Biology 5:423-431.

Kirkham, D., and W. V. Bartholomew. 1954. Equations for following nutrient transformation in soil, utilizing tracer data. Proceedings of the Soil Science Society of America 18:33-34.

Ledgard, S. F., S. C. Jarvis, and D. J. Hatch. 1998. Shortterm nitrogen fluxes in grassland soils under different longterm nitrogen management regimes. Soil Biology and Biochemistry 30:1233-1241.

Lovett, G., K. C. Weathers, and M. A. Arthur. 2002. Control of nitrogen loss from forested watersheds by soil carbon : nitrogen ratio and tree species composition. Ecosystems 5:712-718.

Low, A. P., J. M. Stark, and L. M. Dudley. 1997. Effects of soil osmotic potential on nitrification, ammonification, $\mathrm{N}$ assimilation and nitrous oxide production. Soil Science 162:16-27.

Mack, M. C., and C. M. D'Antonio. 2003. Exotic grasses alter controls over soil nitrogen dynamics in a Hawaiian woodland. Ecological Applications 13:154-166.

Mary, B., S. Recous, and D. Robin. 1998. A model for calculating nitrogen fluxes in soil using ${ }^{15} \mathrm{~N}$ tracing. Soil Biology and Biochemistry 30:1963-1979.

Mikan, C. J., D. R. Zak, M. E. Kubiske, and K. S. Pregitzer. 2000. Combined effects of atmospheric $\mathrm{CO}_{2}$ and $\mathrm{N}$ availability on the belowground carbon and nitrogen dynamics of aspen mesocosms. Oecologia 124:432-445.
Mintie, A. T., R. S. Heichen, K. Cromack, D. D. Myrold, and P. J. Bottomley. 2003. Ammonia-oxidizing bacteria along meadow-to-forest transects in the Oregon Cascade mountains. Applied and Environmental Microbiology 69:31293136.

Müller, C., R. J. Stevens, and R. J. Laughlin. 2004. A N-15 tracing model to analyse $\mathrm{N}$ transformations in old grassland soil. Soil Biology and Biochemistry 36:619-632.

Murphy, D. V., N. B. Dise, K. W. T. Goulding, J. MacDonald, C. Peake, P. Redfern, and E. Stockdale. 2001. Can concepts of $\mathrm{N}$ saturation developed for forest systems be applied in arable soils? Pages 233-238 in R. M. Rees, B. C. Ball, C. D. Campbell, and C. A. Watson, editors. Sustainable management of soil organic matter. CAB International, Wallingford, UK.

Myrold, D. D. 1998. Transformations of nitrogen. Pages 259294 in D. M. Sylvia, J. J. Fuhrmann, P. G. Hartel, and D. A. Zuberer, editors. Principles and applications of soil microbiology. Prentice Hall, Upper Saddle River, New Jersey, USA.

Neff, J. C., A. R. Townsend, G. Gleixner, S. J. Lehman, J. Turnbull, and W. D. Bowman. 2002. Variable effects of nitrogen additions on the stability of turnover of soil carbon. Nature 419:915-917.

Nishio, T., M. Komada, T. Arao, and T. Kanamori. 2001. Simultaneous determination of transformation rates of nitrate in soil. Japan Agricultural Research Quarterly 35:11-17.

Nishio, T., H. Sekiya, K. Toriyama, and K. Kogano. 1994. Changes in gross rates of nitrogen transformations in soil caused by conversion of paddy fields to upland fields. Soil Science and Plant Nutrition 40:301-309.

Norton, J. M., and M. K. Firestone. 1996. N dynamics in the rhizosphere of Pinus ponderosa seedlings. Soil Biology and Biochemistry 28:351-362.

Persson, T., A. Rudebeck, J. H. Jussy, M. Colin-Belgrand, A. Priemé, E. Dambrine, P. S. Karlsson, and R. M. Sjöberg. 2000. Soil nitrogen turnover-mineralization, nitrification and denitrification in European forest soils. Pages 295-331 in E.-D. Schulze, editor. Carbon and nitrogen cycling in European forest ecosystems. Springer-Verlag, Berlin, Germany.

Pilbeam, C. J., B. S. Mahapatra, and M. Wood. 1993. Soil matric potential effects on gross rates of nitrogen mineralization in an Orthic Ferralsol from Kenya. Soil Biology and Biochemistry 25:1409-1413.

Priha, O., T. Hallantie, and A. Smolander. 1999. Comparing microbial biomass, denitrification enzyme activity, and numbers of nitrifiers in the rhizospheres of Pinus sylvestris, Picea abies and Betula pendula seedlings by microscale methods. Biology and Fertility of Soils 30:14-19.

Rice, C. W., and J. M. Tiedje. 1989. Regulation of nitrate assimilation by ammonium in soils and in isolated soil microorganisms. Soil Biology and Biochemistry 21:597-602.

Richter, M., U. A. Hartwig, E. Frossard, J. Nösberger, and G. Cadisch. 2003. Gross fluxes of nitrogen in grassland soil exposed to elevated atmospheric $p \mathrm{CO} 2$ for seven years. Soil Biology and Biochemistry 35:1325-1335.

Riley, R., and P. M. Vitousek. 1995. Nutrient dynamics and nitrogen trace gas flux during ecosystem development in montane rain forest. Ecology 76:292-304.

Roscoe, R., P. Buurman, E. J. Velthorst, and C. A. Vasconcellos. 2001. Soil organic matter dynamics in density and particle size fractions as revealed by the ${ }^{13} \mathrm{C} /{ }^{12} \mathrm{C}$ isotopic ratio in a Cerrado's oxisol. Geoderma 104:185-202.

Ross, D. J., N. A. Scott, K. R. Tate, N. J. Rodda, and J. A. Townsend. 2001. Root effects on soil carbon and nitrogen cycling in a Pinus radiata D. Don plantation on a coastal sand. Australian Journal of Soil Research 39:1027-1039.

Saetre, P., and J. M. Stark. 2005. Microbial dynamics and carbon and nitrogen cycling following rewetting of soils beneath two semi-arid plant species. Oecologia. 142:247260. 
Schimel, J. P., and J. Bennett. 2004. Nitrogen mineralization: challenges of a changing paradigm. Ecology 85:591-602.

Schimel, J. P., M. K. Firestone, and K. S. Killham. 1984. Identification of heterotrophic nitrification in a Sierran forest soil. Applied and Environmental Microbiology 48:802-806.

Schimel, J. P., and M. N. Weintraub. 2003. The implication of exoenzyme activity on microbial carbon and nitrogen limitation in soil: a theoretical model. Soil Biology and Biochemistry 35:549-563.

Schmidt, I. K., S. Jonasson, G. R. Shaver, A. Michelsen, and A. Nordin. 2002. Mineralization and allocation of nutrients by plants and microbes in four arctic ecosystems: responses to warming. Plant and Soil 242:93-106.

Scott, N. A., R. L. Parfitt, D. J. Ross, and G. J. Salt. 1998. Carbon and nitrogen transformations in New Zealand plantation forest soils from sites with different $\mathrm{N}$ status. Canadian Journal of Forest Research 28:967-976.

Shaw, M. R., and J. Harte. 2001. Response of nitrogen cycling to simulated climate change: differential responses along a subalpine ecotone. Global Change Biology 7:193210 .

Shi, W., B. E. Miller, J. M. Stark, and J. M. Norton. 2004. Microbial nitrogen transformations in response to treated dairy waste in agricultural soils. Soil Science Society of America Journal 68:1867-1874.

Shi, W., and J. M. Norton. 2000. Microbial control of nitrate concentrations in an agricultural soil treated with dairy waste compost or ammonium fertilizer. Soil Biology and Biochemistry 32:1453-1457.

Sias, S. R., and J. L. Ingraham. 1979. Isolation and analysis of mutants of Pseudomonas aeruginosa unable to assimilate nitrate. Archives of Microbiology 122:263-270.

Silver, W. L., D. J. Herman, and M. K. Firestone. 2001. Dissimilatory nitrate reduction to ammonium in upland tropical forest soils. Ecology 82:2410-2416.

Smith, J. S., and E. A. Paul. 1990. The significance of soil microbial biomass estimations. Pages 357-369 in J. M. Bollag and G. Stotzky, editors. Soil biochemistry. Marcel Dekker, New York, New York, USA.

Sollins, P., C. A. Glassman, E. A. Paul, C. Swanston, K. Lajtha, J. W. Heil, and E. T. Elliot. 1999. Soil carbon and nitrogen: pools and fractions. Pages 89-105 in G. P. Robertson, D. C. Coleman, C. Bledsoe, and P. Sollins, editors. Standard methods for long-term ecological research. Oxford University Press, New York, New York, USA.

Sparling, G. P., D. V. Murphy, R. B. Thompson, and I. R. P. Fillary. 1995. Short-term net N mineralization from plant residues and gross and net $\mathrm{N}$ mineralization from soil organic matter after rewetting of a seasonally dry soil. Australian Journal of Soil Research 33:961-973.

SPSS. 1996. SYSTAT for Windows. Release 6.1. SPSS, Chicago, Illinois, USA.

Stark, J. M. 1991. Environmental factors versus ammoniaoxidizer population characteristics as dominant controllers of nitrification in an oak woodland-annual grassland soil. Dissertation. University of California, Berkeley, California USA.

Stark, J. M. 1996. Modeling the temperature response of nitrification. Biogeochemistry 35:433-445.

Stark, J. M., and M. K. Firestone. 1995. Mechanisms for soil moisture effects on activity of nitrifying bacteria. Applied and Environmental Microbiology 61:218-221.
Stark, J. M., and S. C. Hart. 1997. High rates of nitrification and nitrate turnover in undisturbed coniferous forests. $\mathrm{Na}$ ture 385:61-74.

Stark, J. M., D. R. Smart, S. C. Hart, and K. A. Haubensak. 2002. Regulation of nitric oxide emissions from forest and rangeland soils of western North America. Ecology 83: 2278-2292.

Stockdale, E. A., D. J. Hatch, D. V. Murphy, S. F. Ledgard, and C. J. Watson. 2002. Verifying the nitrification to immobilisation ratio (N/I) as a key determinant of potential nitrate loss in grassland and arable soils. Agronomie 22: 831-838.

Trumbore, S. E. 1997. Potential responses of soil organic carbon to global environmental change. Proceedings of the National Academy of Sciences 94:8284-8291.

Unkovich, M., N. Jamieson, R. Monaghan, and D. Barraclough. 1998. Nitrogen mineralisation and plant nitrogen acquisition in a nitrogen-limited calcareous grassland. Environmental and Experimental Botany 40:209-219.

Van't Riet, J., A. H. Stouthammer, and R. J. Planta. 1968. Regulation of nitrate assimilation and nitrate respiration in Aerobacter aerogenes. Journal of Bacteriology 96:14551464.

Wang, W., C. J. Smith, P. M. Chalk, and D. Chen. 2001 Evaluating chemical and physical indices of nitrogen mineralization capacity with an unequivocal reference. Soil Science Society of America Journal 65:368-376.

Wang, Y., R. Amundson, and S. E. Trumbore. 1999. The impact of land use change on $\mathrm{C}$ turnover in soils. Global Biogeochemical Cycles 13:47-57.

Wessel, W. W., and A. Tietema. 1992. Calculating gross N transformation rates of ${ }^{15} \mathrm{~N}$ pool dilution experiments with acid forest litter: analytical and numerical approaches. Soil Biology and Biochemistry 24:931-942.

Whalen, J. K., P. J. Bottomley, and D. D. Myrold. 2000. Carbon and nitrogen mineralization from light- and heavyfraction additions to soil. Soil Biology and Biochemistry 32:1345-1352.

Williams, M. A., C. W. Rice, and C. E. Owensby. 2001. Nitrogen competition in a tallgrass prairie ecosystem exposed to elevated carbon dioxide. Soil Science Society of America Journal 65:340-346.

Willison, T. W., J. C. Baker, and D. V. Murphy. 1998a. Methane fluxes and nitrogen dynamics from a drained fenland peat. Biology and Fertility of Soils 27:279-283.

Willison, T. W., J. C. Baker, D. V. Murphy, and K. W. T. Goulding. 1998b. Comparison of a wet and dry N-15 isotopic dilution technique as a short-term nitrification assay. Soil Biology and Biochemistry 30:661-663.

Zak, D., K. S. Pregitzer, P. S. Curtis, J. A. Teeri, R. Fogel, and D. A. Randlett. 1993. Elevated atmospheric $\mathrm{CO}_{2}$ and feedback between carbon and nitrogen cycles. Plant and Soil 151:105-117.

Zak, D. R., D. Tilman, R. R. Parmenter, C. W. Rice, F. M. Fisher, J. Vose, D. Milchunas, and C. W. Martin. 1994. Plant production and soil microorganisms in late-successional ecosystems: a continental-scale study. Ecology 75: 2333-2347.

Zaman, M., H. J. Di, K. C. Cameron, and C. M. Frampton. 1999. Gross nitrogen mineralization and nitrification rates and their relationships to enzyme activities and the soil microbial biomass in soils treated with dairy shed effluent and ammonium fertilizer at different water potentials. Biology and Fertility of Soils 29:178-186.

\section{APPENDIX}

A list of the references containing data used in the analyses is available in ESA's Electronic Data Archive: Ecological Archives M075-005-A1. 